\title{
Synopsis of the
}

Parasites of

Edited by Murray J. Kennedy

\section{Meningeal Worm and its Close Relatives}

W.M. Samuel 
Copies of this publication are available from the Queen's Printer, 11510 Kingsway Avenue, Edmonton T5G 2Y5

Orders for this publication must be accompanied by a cheque that is made payable to THE PROVINCIAL TREASURER 


\title{
Synopsis of the
}

Parasites of

Edited by Murray J. Kennedy ${ }^{1}$

\section{A Partially Annotated Bibliography of Meningeal Worm, Parelaphostrongylus tenuis (Nematoda), and Its Close Relatives}

W.M. Samuel2

\author{
${ }^{1}$ Alberta Agriculture \\ Veterinary Laboratory \\ 6909 - 116 Street \\ Edmonton, Alberta \\ Canada T6H 4P2 \\ 2 Department of Zoology \\ University of Alberta \\ Edmonton, Alberta \\ Canada T6G 2E9
}





\section{CONTENTS}

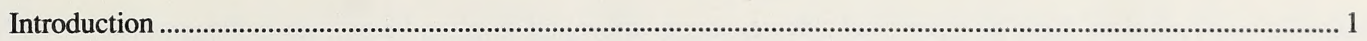

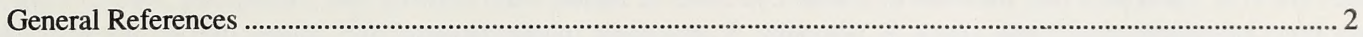

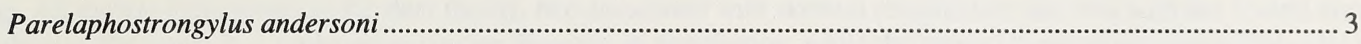

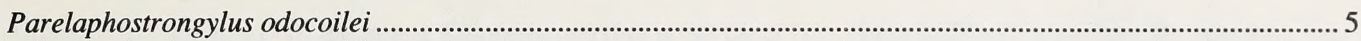

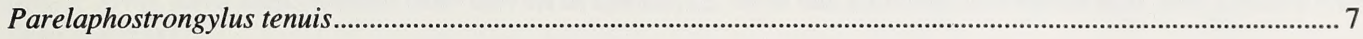

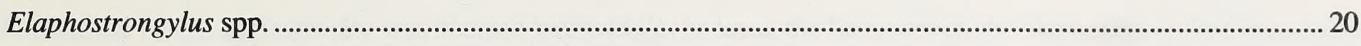

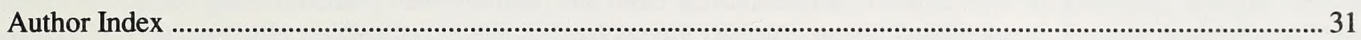

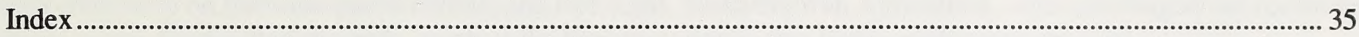


Digitized by the Internet Archive in 2016 
INTRODUCTION

The elaphostrongylines are a small group of lungworm nematodes that have received much attention from scientists because of neurologic disease, pneumonia, and myositis often caused by them in a variety of domestic and wild hosts. In North America, four species representing two genera, Parelaphostrongylus anderson, P. odocoilei, P. tenuis, and Elaphostrongylus cervin, comprise the group. All mature in members of the deer family, two associated with skeletal musculature and two with the central nervous system. Members of the genus Parelaphostrongylus are Nearctic in distribution, while the genus Elaphostrongylus is Holarctic in distribution.

Although the taxonomy of the genus Elaphostrongylus is not clear (ie., there is debate regarding the species), four species, including $E$. cervin, have been reported from cervids of Eurasia (E. cervi has also been introduced into New Zealand where it is known only from red deer).

Publication of this bibliography was deemed worthwhile, because the literature on the elaphostrongyline nematodes is of interest to wildlife biologists, game ranchers, veterinarians, and other agriculturalists. I thank: Murray Kennedy, Alberta Agriculture, who encouraged and assisted with publication in this Animal Health Division series; Laszlo Sugar, Pannan Agricultural University, who provided comments on Eurasian-based entries; and Ron Lind, Saskatchewan Agriculture, who encouraged our recent research on meningeal worm. During that research, much of the literature used in this bibliography was acquired.

References are arrayed numerically and alphabetically under headings, "GENERAL REFERENCES, PARELAPHOSTRONGYLUS ANDERSON, PARELAPHOSTRONGYLUS ODOCOILEI, PARELAPHOSTRONGYLUS TENUIS, and ELAPHOSTRONGYLUS SPP.", The numbering system is progressive under each heading except for a few references with information that covers more than one heading. Thus, for example, reference number 12 is found under all three species of Parelaphostrongylus.

1 


\section{GENERAL REFERENCES}

1. ANDERSON, R.C. 1978. No. 5, Keys to the genera of the superfamily Metastrongyloidea. In R.C. Anderson, A.G. Chabaud, and S. Willmott, eds. CIH Keys to the nematode parasites of vertebrates. Farnham Royal, Bucks, England. Commonwealth Agricultural Bureaux.

2. BOEV, S.N. 1968. (Revision of the subfamily Elaphostrongylinae, parasites of the brain of deer). Parazitologia 2: 312-316.

Reviews genera Elaphostrongylus, Parelaphostrongylus and Odocoileostrongylus. Invalidates Parelaphostrongylus because type species $P$. odocoilei is considered species inquirenda (see Platt and Samuel, 1978).

3. BOEV, S.N. 1975. (Protostrongylids). Osnovy

Nematodologii, 25, Akademii Nauk SSR, Gel'mintologicheskoi Laboratorii, Nauka Publishers, Moscow, 266 p.

4. BOEV, S.N. 1984. Protostrongylids. Fundamentals of Nematology, volume 25, Academy of Sciences of the USSR, Helminthological Laboratory, Nauka Publishers, Moscow, 266p.

Translation of previous citation. Published for the United States Department of Agriculture and the National Science Foundation, Washington, D.C., by Amerind Publishing Co., Pvt. Ltd., New Delhi. Available from the United States Department of Commerce, National Technical Information Service, Springfield, Virginia 22161.

5. BOEV, S.N., and R.S. SCHUL'TS. 1950. (Reconstruction of the systematics of the nematode family Protostrongylidae Leiper, 1926). Doklady Akademii Nauk SSSR 70: 355-358.

6. FORRESTER, D.J., G.M. FORRESTER, and C.M. SENGER. 1966. A contribution toward a bibliography on the lung nematodes of mammals. Journal of Helminthology 40 (Supplement): 1-122.

7. GRAY, J.B., W.M. SAMUEL, A.W. SHOSTAK, and M.J. PYBUS. 1985. Varestrongylus alpenae (Nematoda: Metastrongyloidea) in white-tailed deer (Odocoileus virginianus) of Saskatchewan. Canadian Journal of Zoology 63: 1449-1454.

Varestrongylus alpenae occurred in the lung parenchyma of 19 per cent of the white- tailed deer of eastern Saskatchewan. Mule deer and white-tailed deer were infected experimentally. Mule deer had a prepatent period of 43-49 days; white-tailed deer, 54-55 days. Lengths of larvae of all known lungworms in hoofed mammals of North America producing single dorsal-spined first stage larvae are reviewed.

8. GRAY, J.B., R.A. KRALKA, and W.M. SAMUEL. 1985. Rearing of eight species of terrestrial gastropods (order Stylommatophora) under laboratory conditions. Canadian Journal of Zoology 63: 2474-2476.
Includes techniques for rearing, and maintenance of known intermediate hosts for Parelaphostrongylus spp.

9. HAIGH, J.C. 1989. Brain and múscle worms. Game Farming Practice. Notes for the game farming industry. $4 \mathrm{pp}$.

A short review written for game growers.

10. KARSTAD, L. 1964. Diseases of the cervidae; a partly annotated bibliography. Wildlife Disease, Number 43, $233 \mathrm{pp}$.

11. KARSTAD, L. 1969. Diseases of the cervidae: bibliographic supplement, I. Wildlife Disease, Number 52, 114 pp. 


\section{PARELAPHOSTRONGYLUS ANDERSONI}

12. BALLANTYNE, R.J., and W.M. SAMUEL. 1984. Diagnostic morphology of the third-stage larvae of three species of Parelaphostrongylus (Nematoda, Metastrongyloidea). Journal of Parasitology 70: 602-604.

See this reference under $P$.tenuis.

13. LANKESTER, M.W., and P.L. HAUTA. 1989. Parelaphostrongylus andersoni (Nematoda: Elaphostrongylinae) in caribou (Rangifer tarandus) of northern and central Canada. Canadian Journal of Zoology 67: 1966-1975.

Report $P$. andersoni in woodland caribou, $R$. $t$. caribou of northwestern Ontario (Slate Islands herd), northern Quebec and Labrador (George River herd), and barren ground caribou, $R$. $t$. groenlandicum, of the central Northwest Territories (Beverly herd). This first report of $P$. andersoni in Rangifer sp. in North America raises the possibility that $P$. andersoni originated in, and may still occur in, cervids of the Old World.

14. LANKESTER, M.W. and D. FONG. 1989. Distribution of elaphostrongyline nematodes (Metastronglyoidea:

Protostrongylidae) in cervidae and possible effects of moving Rangifer spp. into and within North America. Alces 25: 133-145.

See this reference under Elaphostrongylus spp.

15. NETTLES, V.F., and A.K. PRESTWOOD. 1976. Experimental Parelaphostrongylus andersoni infections in white-tailed deer. Veterinary Pathology 13: 381-393.

Adult worms caused eosinophilic myositis in the loin and thigh of deer given 1000 or 5000 larvae. A deer given a moderate dose (200 to 356 larvae) remained patent for more than 1 year and was reinfected. Lung lesions were firm miliary nodules (grossly) and granulomatous encapsulation of eggs and first-stage larvae in alveolar capillaries, accumulations of eosinophils and mononuclear inflammatory cells in the adjacent alveolar septa, congestion, and interstitial pneumonia.

16. PLATT, T.R. 1984. Evolution of the Elaphostrongylinae (Nematoda: Metastrongyloidea: Protostrongylidae) parasites of cervids (Mammalia). Proceedings of the Helminthological Society of Washington 51: 196-204.

See this reference in $P$. tenuis section.

17. PRESTWOOD, A.K. 1972. Parelaphostrongylus andersoni sp.n. (Metastrongyloidea: Protostrongylidae) from the musculature of the white-tailed deer (Odocoileus virginianus). Journal of Parasitology 58: 897-902.

Describes new species from musculature of white-tailed deer in coastal Georgia and South Carolina, USA.
18. PRESTWOOD, A.K., and V.F. NETTLES. 1977. Repeated low-level infection of white-tailed deer with Parelaphostrongylus andersoni. Journal of Parasitology 63: 974-978.

Repeated low-level (five larvae/weekday/13wk) infection of $P$. andersoni resulted in a resistance to challenge when followed by a single-dose of 200 larvae at 23 weeks.

19. PRESTWOOD, A.K., V.F. NETTLES, and F.E. KELLOGG. 1974. Distribution of muscle worm, (Parelaphostrongylus andersoni), among white-tailed deer of the southeastern United States. Journal of Wildlife Diseases 10: 404-409.

Parelaphostrongylus andersoni was found in white-tailed deer of Florida, Georgia, Louisiana, North and South Carolina.

20. PURSGLOVE, S.R. 1977. Helminth parasites of white-tailed deer (Odocoileus virginianus) from New Jersey and Oklahoma. Proceedings of the Helminthological Society of Washington 44: 107-108.

Parelaphostrongylus andersoni and P. tenuis were found in one and four of 10 white-tailed deer, respectively, from New Jersey.

21. PYBUS, M.J. 1983. Parelaphostrongylus andersoni Prestwood 1972 and P. odocoilei (Hobmaier and Hobmaier 1934) (Nematoda: Metastrongyloidea) in two cervid definitive hosts. Ph.D. Thesis, University of Alberta, Edmonton, 185pp.

22. PYBUS, M.J., and W.M. SAMUEL. 1981. Nematode muscleworm from white-tailed deer of southeastern British Columbia. Journal of Wildlife Management 45: 537-542.

Seventy four per cent of 103 white-tailed deer had dorsal-spined larvae in their feces, the number averaging 40 per gram of feces. Two captive deer were infected experimentally with larvae from the wild source and only $P$. andersoni were recovered.

23. PYBUS, M.J., and W.M. SAMUEL. 1984.

Parelaphostrongylus andersoni (Nematoda:

Protostrongylidae) and $P$. odocoilei in two cervid definitive hosts. Journal of Parasitology 70: 507-515.

An experimental study of comparative infectivity, location and production of larvae of adult $P$. andersoni and $P$. odocoile $i$ was conducted in white-tailed deer and mule deer. Mule deer were successfully infected with $P$. andersoni.

24. PYBUS, M.J., and W.M. SAMUEL. 1984. Attempts to find a laboratory host for Parelaphostrongylus andersoni and Parelaphostrongylus odocoilei (Nematoda: 
Protostrongylidae). Canadian Journal of Zoology 62:

1181-1184.

Twenty guinea pigs, eight domestic rabbits, and three domestic goats were exposed to $P$. andersoni or $P$. odocoilei. No patent infections occurred. Larvae in the guinea pig and rabbit did not reach skeletal muscles, the usual site for adult worms.

25. SAMUEL, W.M., and J.B. GRAY. 1988. Efficacy of ivermectin against Parelaphostrongylus andersoni (Nematoda, Metastrongyloidea) in white-tailed deer (Odocoileus virginianus). Journal of Wildlife Diseases 24: 491-495.

Ivermectin given subcutaneously at 200 and $400 \mu \mathrm{g} / \mathrm{kg}$ body weight resulted in elimination of larvae in deer feces for several weeks, after which larvae reappeared in feces of most deer.

26. PYBUS, M.J., W.M. SAMUEL, D.A. WELCH, and C.J. WILKE. 1990. Parelaphostrongylus andersoni (Nematoda: Protostrongylidae) in white-tailed deer in Michigan. Journal of Wildlife Diseases 26:535-537.

Larvae from deer feces (collected in Michigan) were passed through snails and a captive fawn white-tailed deer; adult $P$. andersoni were recovered later. Adds to published records for $P$. andersoni in deer from the southeastern United States, New Jersey, and British Columbia, Canada. 


\section{PARELAPHOSTRONGYLUS ODOCOILEI}

12. BALLANTYNE, R.J., and W.M. SAMUEL. 1984.

Diagnostic morphology of the third-stage larvae of three species of Parelaphostrongylus (Nematoda,

Metastrongyloidea). Journal of Parasitology 70: 602-604.

See this reference in $P$. tenuis section.

27. BRUNETTI, O.A. 1969. Redescription of Parelaphostrongylus (Boev and Schulz, 1950) in California deer, with studies on its life history and pathology. California Fish and Game 55: 307-316.

Parelaphostrongylus odocoilei is redescribed from California mule deer, Odocoileus hemionus californicus and the type host, black-tailed deer (Odocoileus hemionus columbianus) and type locality (California).

28. GRAY, J.B., and W.M. SAMUEL. 1986.

Parelaphostrongylus odocoilei (Nematoda:

Protostrongylidae) and a protostrongylid nematode in woodland caribou (Rangifer tarandus caribou) of Alberta, Canada. Journal of Wildlife Diseases 22: 48-50.

Twenty eight per cent of woodland caribou of west-central Alberta were infected with $P$. odocoilei based on detection of larvae in feces and passage of these larvae through snails and recovery of adult worms from experimentally infected mule deer. Presence of large spined first-stage larvae in feces of caribou from northeastern Alberta suggested the possible presence of a worm other than $P$. odocoilei, perhaps Elaphostrongylus cervi.

29. HOBMAIER, M. 1937. Studies on the pathology of Elaphostrongylus odocoilei in Odocoileus columbianus columbianus. Raboty Gel'mint.: 235-240.

First study describing parasitic lesions in the lungs of North American deer.

30. HOBMAIER, A., and M. HOBMAIER. 1934.

Elaphostrongylus odocoilei $\mathrm{n} . \mathrm{sp}$., a new lungworm in black-tailed deer (Odocoileus columbianus). Description and life history. Proceedings of the Society for Experimental Biology and Medicine 31: 509-514.

Describes connective tissue nematode associated with the musculature of Columbian black-tailed deer of the coastal range of central California, USA (see reference number 27).

14. LANKESTER, M.W., and D. FONG. 1989. Distribution of elaphostrongyline nematodes (Metastronglyoidea:

Protostrongylidae) in cervidae and possible effects of moving Rangifer spp. into and within North America. Alces 25: 133-145.

See this reference under Elaphostrongylus spp.
31. PLATT, T.R. 1978. The life cycle and systematics of Parelaphostrongylus odocoilei (Nematoda:

Metastrongyloidea), a parasite of mule deer (Odocoileus hemionus hemionus), with special reference to the molluscan intermediate host. Ph.D. Thesis, Univesity of Alberta, Edmonton. 233pp.

16. PLATT, T.R. 1984. Evolution of the Elaphostrongylinae (Nematoda: Metastrongyloidea: Protostrongylidae) parasites of cervids (Mammalia). Proceedings of the Helminthological Society of Washington 51: 196-204.

See this reference in $P$. tenuis section.

32. PLATT, T.R., and W.M. SAMUEL. 1978. A redescription and neotype designation for Parelaphostrongylus odocoilei (Nematoda: Metastrongyloidea). Journal of Parasitology 64: 226-232.

Redescribe $P$. odocoilei using specimens of Brunetti (1969) from the type host, Odocoileus hemionus californicus, in California and from experimentally infected Rocky Mountain mule deer, Odocoileus hemionus hemionus, using source larvae from mule deer of Jasper National Park, Alberta, Canada. Designated one of the California specimens (see Brunetti, 1969) as the new type.

33. PLATT, T.R., and W.M. SAMUEL. 1978.

Parelaphostrongylus odocoilei: life cycle in experimentally infected cervids including the mule deer, Odocoileus h. hemionus. Experimental Parasitology 46: 330-338.

Experimentally completed the life cycle in mule deer (Odocoileus $h$. hemionus), black-tailed deer ( $O$. h. columbianus), and moose (Alces alces andersoni), but not white-tailed deer ( $O$. virginianus dacotensis). The prepatent period was shorter and the duration and intensity of larval production longer and higher in mule deer than in the moose or black-tailed deer.

34. PLATT, T.R., and W.M. SAMUEL. 1984. Mode of entry of first-stage larvae of Parelaphostrongylus odocoilei (Nematoda: Metastrongyloidea) into four species of terrestrial gastropods. Proceedings of the Helminthological Society of Washington 51: 205-207.

Direct penetration of the ventral epithelium was the predominant mode of entry of $P$. odocoilei larvae in the slug Deroceras laeve, a major intermediate host of Parelaphostrongylus spp.

21. PYBUS, M.J. 1983. Parelaphostrongylus andersoni Prestwood 1972 and P. odocoilei (Hobmaier and Hobmaier 1934) (Nematoda: Metastrongyloidea) in two cervid definitive hosts. Ph.D. Thesis, University of Alberta, Edmonton, 185pp. 
35. PYBUS, M.J., and W.M. SAMUEL. 1980. Pathology of the muscleworm, Parelaphostrongylus odocoilei (Nematoda: Metastrongyloidea), in moose. Proceedings of the North American Moose Conference and Workshop 16: 152-170.

Describe lesions in two moose calves experimentally infected with $P$. odocoilei and compared them to lesions seen in the usual host, mule deer. Necrosis and destruction of muscle tissue was severe in moose, but no clinical signs of disease occurred.

23. PYBUS, M.J., and W.M. SAMUEL. 1984.

Parelaphostrongylus andersoni (Nematoda:

Protostrongylidae) and $P$. odocoilei in two cervid definitive hosts. Journal of Parasitology 70: 507-515.

See this reference in $P$. andersoni section.

24. PYBUS, M.J., and W.M. SAMUEL. 1984. Attempts to find a laboratory host for Parelaphostrongylus andersoni and Parelaphostrongylus odocoilei (Nematoda: Protostrongylidae). Canadian Journal of Zoology 62: 1181-1184.

See this reference in $P$. andersoni section.

36. PYBUS, M.J., and W.M. SAMUEL. 1984. Lesions caused by Parelaphostrongylus odocoilei (Nematoda:

Metastrongyloidea) in two cervid hosts. Veterinary Pathology 21: 425-431.

Pathologic effects and host responses were evaluated in seven white-tailed deer and six mule deer infected experimentally with $P$. odocoilei. Hemorrhagic myositis throughout skeletal muscles, severe verminous pneumonia, moderate lymphadenitis, and a granulomatous inflammation associated with eggs and larvae in the lung were seen in mule deer, while very little was seen in whitetailed deer.

37. PYBUS, M.J., W.J. FOREYT, and W.M. SAMUEL. 1984. Natural infections of Parelaphostrongylus odocoilei (Nematoda: Protostrongylidae) in several hosts and locations. Proceedings of the Helminthological Society of Washington 51: 338-340.

Report $P$. odocoilei in Columbian black-tailed deer, Odocoileus hemionus columbianus, on Vancouver Island, British Columbia, Canada, and mountain goat, Oreamnos americanus, from Washington, USA, and Jasper Park, Alberta, Canada.

38. SAMUEL, W.M., and J.B. GRAY. 1982. Evaluation of the Baermann Technic for recovery of lungworm (Nematoda, Protostrongylidae) larvae from wild ruminants. Biennial Symposium Northern Wild Sheep and Goat Council 3: 232-243.

Using the Baermann Technic, highest numbers of larvae of $P$. odocoilei occurred when 10 grams of fresh mule deer feces were put in 100 milliliters of water in a 10 or 15 centimeter glass funnel and allowed to stand 24 hours.
39. SAMUEL, W.M., T.R. PLATT, and S.M.

KNISPEL-KRAUSE. 1984. Gastropod intermediate hosts and transmission of Parelaphostrongylus odocoilei, a muscle-inhabiting nematode of mule deer, Odocoileus $h$. hemionus, in Jasper National Park, Alberta. Canadian Journal of Zoology 63: 928-932.

Over 11,000 terrestrial gastropods were examined for larvae of muscleworm in Jasper Park, Alberta, Canada. Seven species were infected: Deroceras laeve (5.3\%), Zonitoides nitidus $(1.5 \%)$, Euconulus fulvus (1.3\%), Discus shimeki (1.2\%), Zonitoides arboreus $(0.8 \%)$, Vitrina limpida $(0.7 \%)$, and Discus cronkhitei $(0.6 \%)$. Prevalence of first-stage larvae in deer feces was 92.5 per cent with fewer larvae being shed in summer and maximum numbers shed in March and April. All deer became infected as fawns in autumn.

40. SHOSTAK, A.W., and W.M. SAMUEL. 1984. Moisture and temperature effects of survival and infectivity of first-stage larvae of Parelaphostrongylus odocoilei and $P$. tenuis (Nematoda: Metastrongyloidea). Journal of Parasitology 70: 261-269.

Survival of first-stage larvae of $P$. odocoilei and $P$. tenuis and their infectivity to snails were determined. Survival increased with decreasing temperature and decreased with increasing relative humidity, repeated freezings, and desiccations. Infectivity for snails of $P$. odocoilei first-stage larvae that survived desiccation was poor. Larvae of $P$. odocoilei from mule deer of westcentral Alberta, Canada were better able to resist effects of freezing, but less able to resist effects of desiccation, than were larvae of $P$. tenuis from white-tailed deer of western Pennsylvania, USA. 


\section{PARELAPHOSTRONGYLUS TENUIS}

41. ALDEN, C., F. WOODSON, R. MOHAN, and S. MILLER. 1975. Cerebrospinal nematodiasis in sheep. Journal of the American Veterinary Medical Association 166: 784-786.

The central nervous system of five sheep with various locomotor problems from three farms in West Virginia, USA, had worms tentatively identified as meningeal worm. The cases are described.

42. ALIBASOGLU, M., D.C. KRADEL, and H.W. DUNNE. 1961. Cerebral nematodiasis in Pennsylvania deer (Odocoileus virginianus). Cornell Veterinarian 51: 431-441.

Found adult meningeal worms in heads of 61 of 81 white-tailed deer from western and central Pennsylvania, USA. Intensity ranged from 2 to 20 worms. Owing to clinical observations and histological studies, authors suggest that under some circumstances meningeal worms are responsible for nervous disorders in deer.

43. ANDERSON, R.C. 1956. Elaphostrongylus odocoilei Hobmaier and Hobmaier, 1934 in the cranial case of Odocoileus virginianus borealis Miller. Canadian Journal of Zoology 34: 167-173.

The cranial cases of 10 of 30 white-tailed deer from Algonquin Park, Ontario, Canada, had nematodes in the subarachnoid space. The worms are described and referred to Elaphostrongylus odocoilei (but see Anderson, 1962).

44. ANDERSON, R.C. 1962. The helminth and arthropod parasites of the white-tailed deer (Odocoileus virginianus): A general review. Transactions of the Royal Canadian Institute 34: 57-92.

Reviews taxonomic dilemmas of lungworms of white-tailed deer.

45. ANDERSON, R.C. 1963. The incidence, development, and experimental transmission of Pneumostrongylus tenuis Dougherty (Metastrongyloidea: Protostrongylidae) of the meninges of the white-tailed deer (Odocoileus virginianus borealis) in Ontario. Canadian Journal of Zoology 41: 775-802.

Forty-one per cent of white-tailed deer of Algonquin Park, Ontario, Canada, were infected with meningeal worm. A fawn killed in October was infected. Worms (intensity ranged from 1 to 20) were found on the spinal dura mater and in veins of the dura. Four fawns were infected experimentally. At 25 days, 4 th and 5th stage worms were found in the brain and spinal cord. At 40 days, 5 th stage worms were in nerve tissue and between meninges of the spinal cord. At 50 days, subadults were on the spinal cord and cerebral dura. At 115 days, adults were on or in the cerebral dura and in the intercavernous sinus.

46. ANDERSON, R.C. 1963. Studies on Pneumostrongylus tenuis Dougherty, 1945 of Odocoileus virginianus. Journal of Parasitology 49: 40-47.
The early development $(<40$ days) of meningeal worm in white-tailed deer fawns infected experimentally took place in nerve tissue of central nervous system, after which 5th stage worms moved into the subdural spaces where they matured. Eggs were deposited into veins and formed emboli in lung. Fawns exhibited no neurologic disease.

47. ANDERSON, R.C. 1964. Motor ataxia and paralysis in moose calves infected experimentally with

Pneumostrongylus tenuis (Nematoda:

Metastrongyloides). Northeastern Wildlife Conference, Hartford, Connecticut, Jan. 21: 1-7.

See next reference.

48. ANDERSON, R.C. 1964. Neurologic disěase in moose infected experimentally with Pneumostrongylus tenuis from white-tailed deer. Veterinary Pathology 1: 289-322.

A unique disease "moose sickness" of wild moose was reproduced experimentally in two moose calves infected with white-tailed deer-source $P$. tenuis. Lesions are described histologically.

49. ANDERSON, R.C. 1965. An examination of wild moose exhibiting neurologic signs, in Ontario. Canadian Journal of Zoology 43: 635-639.

Pneumostrongylus tenuis was found in the central nervous system of three wild moose with neurologic signs. Eggs and larvae were found associated with the brain and eye showing that meningeal worm can mature in moose.

50. ANDERSON, R.C. 1965. The development of Pneumostrongylus tenuis in the central nervous system of white-tailed deer. Pathologia veterinaria 2: 360-379.

Examined histological sections from five white-tail fawns experimentally infected with $P$. tenuis and killed 10,20,30, and 40 days after infection. Young worms were in the dorsal horns of the grey matter of the spinal cord in 10-30 day-infected fawns. At 40 days, worms were in the subdural space. Saw very little host response compared to moose indicating perhaps a long wellestablished host-parasite relationship.

51. ANDERSON, R.C. 1965. Cerebrospinal nematodiasis (Pneumostrongylus tenuis) in North American cervids. Transactions of the North American Wildlife and Natural Resources Conference 13: 156-167.

A review for wildlife specialists of current knowledge on meningeal worm. Provides evidence that meningeal worm is the agent causing neurologic disease in moose and suggests that moose may have recently come into contact with this parasite as a result of northward extension of the range of white-tailed deer in North America.

52. ANDERSON, R.C. 1966. Cerebrospinal nematodiasis (Pneumostrongylus tenuis) in north American ruminants. 
(Abstract) Proceedings of the 1st International Congress of Parasitology, Rome, Volume I: 461-462.

53. ANDERSON, R.C. 1967. Neurotropic and accidental nematode parasites of the central nervous system of animals. South Pacific Commission Seminar on Helminthiases and Eosinophilic Meningitis, Noumea, New Caledonia, June 5-16, 12pp (mimeo).

54. ANDERSON, R.C. 1968. The pathogenesis and transmission of neurotropic and accidental nematode parasites of the central nervous system of mammals and birds. Helminthological Abstracts 37: 191-210.

Reviews pathogenicity of elaphostrongyline nematodes and suggests that $E$. cervi may not be an accidental parasite of the central nervous system as suggested previously (Lubimov, 1959).

55. ANDERSON, R.C. 1970. The ecological relationships of meningeal worm (Pneumostrongylus tenuis Dougherty, 1945) and native cervids in North America. (Abstract) Journal of Parasitology (Section 2, Part 1) 56(4), (Proceedings of the 2nd International Congress of Parasitology, Washington, D.C.) pp. 6-7.

56. ANDERSON, R.C. 1971. Neurologic disease in reindeer (Rangifer tarandus tarandus) introduced into Ontario. Canadian Journal of Zoology 49: 159-166.

Twelve reindeer from Norway were released on an island in Georgian Bay of Lake Huron, Ontario, Canada in early May, 1969. White-tailed deer were abundant on the island. Signs of neurologic disease became apparent by early August, 1969. By the following July, seven reindeer had succumbed to neurologic disease and four of the five survivors were clinically ill.

57. ANDERSON, R.C. 1971. Lungworms. In: Davis, J.W., and R.C. Anderson (eds.), Parasitic diseases of wild mammals. The Iowa State University Press, Ames, Iowa. pp. 81-126.

Reviews meningeal worm and related species of wild mammals.

58. ANDERSON, R.C. 1972. The ecological relationships of meningeal worm and native cervids in North America. Journal of Wildlife Diseases 8: 304-310.

Suggests that alterations in the North American environment in the last 100 years resulted in a great expansion of the northern range of the white-tailed deer. This resulted in increased contact between white-tailed deer and a variety of native Cervidae, all susceptible to neurologic disease caused by meningeal worm and carried by the normal host, the white-tailed deer. Suggests that the parasite is spreading westward in Canada with expanding deer populations.

59. ANDERSON, R.C. 1975. Disease and the management of moose. Proceedings of the North American Moose Conference and Workshop 11: 318-331.

Diseases and parasites reported in moose of North America are classified and discussed according to their actual or potential importance in management. Parelaphostrongylosis is the only disease known to affect moose populations.
60. ANDERSON, R.C. 1984. Parelaphostrongylosis caused by the meningeal worm, Parelaphostrongylus tenuis.

A slide, tape, text program available through: Educational Aids, Wildlife Disease Association, P.O. Box 886, Ames, Iowa, 31 pp. and 59 color, $35 \mathrm{~mm}$ slides.

61. ANDERSON, R.C., and U.R. STRELIVE. 1966. The transmission of Pneumostrongylus tenuis to guinea pigs. Canadian Journal of Zoology 44: 533-540.

Meningeal worm did not mature in guinea pigs nor were many worms recovered at necropsy. Some animals developed neurologic signs with posterior paralysis being the predominant clinical sign.

62. ANDERSON, R.C., and U.R. STRELIVE. 1966. Experimental cerebrospinal nematodiasis (Pneumostrongylus tenuis) in sheep. Canadian Journal of Zoology 44: 889-894.

Six lambs were infected with between 50 and 1,000 larvae of meningeal worm. Three animals developed neurologic signs and died; the lamb given 1,000 larvae died 15 days post-exposure while the others died at days 64 and 84 . Results suggest that sheep have some resistance to infection and that worms did not mature in lambs.

63. ANDERSON, R.C., and U.R. STRELIVE. 1967. The penetration of Pneumostrongylus tenuis into the tissues of white-tailed deer. Canadian Journal of Zoology 45: 285-289.

Three fawns exposed to many larvae of meningeal worm were killed within six days. Larvae left the gut via the abomasal wall and were found in the mesenteries and omentum. Found eosinophilic infiltrations associated with the nerves ventral to the lumbo-sacral region suggesting migration of larvae from the peritoneal cavity to the spinal cord.

64. ANDERSON, R.C., and U.R. STRELIVE. 1968. The experimental transmission of Pneumostrongylus tenuis to caribou (Rangifer tarandus terraenovae). Canadian Journal of Zoology 46: 503-510.

Two caribou calves developed neurologic signs within a week of exposure to meningeal worm larvae. One died on day 14 from a fungal infection, the other died on day 29 of severe neurologic disease. Authors suggest that this host is more sensitive to meningeal worm than moose, elk, or mule deer. Worms, obviously immature, and lesions were numerous in the spinal cord, brain stem, and medulla oblongata.

65. ANDERSON, R.C., and U.R. STRELIVE. 1969. The effect of Pneumostrongylus tenuis (Nematoda:

Metastrongyloidea) on kids. Canadian Journal of Comparative Medicine 33: 280-286.

Young kids 6 to 28 weeks old were infected with 200 to 1,000 meningeal worm larvae. Nine died of peritonitis and colitis within 11 days after infection. Two developed clinical neurologic signs 18 and 38 days after infection. 
66. ANDERSON, R.C., and U.R. STRELIVE. 1972.

Experimental cerebrospinal nematodiasis in kids. Journal of Parasitology 58: 816.

Twelve kids were exposed to meningeal worm larvae by intraperitoneal injection. All kids developed neurologic disease. Small numbers of $P$. tenuis were found in the CNS.

67. ANDERSON, R.C., and M.W. LANKESTER. 1974. Infectious and parasitic diseases and arthropod pests of moose in North America. le Naturaliste Canadien 101: 23-50.

A general review of helminths of moose. Meningeal worm is given special mention. Authors suggest that moose are relatively recent immigrants to North America and that they brought relatively few parasites with them to North America. Meningeal worm was probably acquired from native deer (Odocoileus).

68. ANDERSON, R.C., and A.K. PRESTWOOD. 1981.

Lungworms. In: Davidson, W.R., F.A. Hayes, V.F.

Nettles, and F.E. Kellogg (eds.) Diseases and parasites of white-tailed deer. Miscellaneous Publications Number 7, Tall Timbers Research Station, Tallahassee, FL. pp.

266-317.

Book chapter that contains extensive review of meningeal worm and related lungworms of white-tailed deer.

69. ANDERSON, R.C., M.W. LANKESTER, and U.R. STRELIVE. 1966. Further experimental studies of Pneumostrongylus tenuis in cervids. Canadian Journal of Zoology 44: 851-861.

Two young elk calves and one mule deer fawn were infected with meningeal worm of whitetail origin. One elk died of neurologic disease 54 days post-exposure while the second showed slight signs, survived, and shed larvae in feces beginning day 92 post-exposure. The mule deer died of neurologic disease at day 62 post-exposure. The elk and mule deer had severe lesions in the dorsal horns. Notes possibility that meningeal worm could become established in elk introduced into eastern North America.

70. ANDERSSON, P., M. VALTONEN, T. RAITIS, and I. KOIVISTO. 1969. An attempt to find Pneumostrongylus tenuis in Finland. Finnish Game Research 31: 10-12.

Seven 4-month-old white-tailed deer from Minnesota were released near Vesilahti in 1938 and 1948. By 1966, the population had spread considerably and grown in numbers to 4,000 . In 1966 and 1967, 77 whitetails, three moose and two fallow deer were necropsied for meningeal worm; none was found

71. ARCHIBALD, R.M. 1960. Listeria monocytogenes from a Nova Scotia moose. Canadian Veterinary Journal 1: 225-226.

Listeria monocytogenes was isolated from the brain of a moose with "moose sickness."

12. BALLANTYNE, R.J., and W.M. SAMUEL. 1984. Diagnostic morphology of the third-stage larvae of three species of Parelaphostrongylus (Nematoda, Metastrongyloidea). Journal of Parasitology 70: 602-604.

Differentiated the infective, third-stage larvae of $P$. tenuis, $P$. odocoilei, and $P$. andersoni using light microscopy by the shape of the tails. First-stage larvae of all three species were morphologically indistinguishable.

72. BARBEHENN, K.R. 1969. Host-parasite relationships and species diversity in mammals: an hypothesis. Biotropica 1: 29-35.

Presents the hypothesis that one way to increase regional species diversity is by the joining of congeners (e.g., moose and white-tailed deer) that have evolved in geographic isolation. One mechanism proposed whereby this joining could result is the presence of a parasite (e.g., meningeal worm) that is well adapted to one host (e.g., white-tailed deer) and deleterious to the other host (e.g., moose). The original relationship of the one example mentioned $(P$. tenuis) is difficult to assess due to the fact that, around the turn of the century, man cut and burned parts of the southern Boreal Forest thus creating excellent deer habitat.

73. BARRETT, M.W. 1972. A review of the diet, condition, diseases and parasites of the Cypress Hills moose. Proceeding of the North American Moose Conference and Workshop 8: 60-79.

74. BAUMGARTNER, W., A. ZAJAC, B.L. HULL, F. ANDREWS, and F. GARRY. 1985.

Parelaphostrongylosis in llamas. Journal of the American Veterinary and Medical Association 187: 1243-1245.

Two of 15 llamas in Ohio had a gradual 7- to 10-day onset of posterior ataxia and weakness. When presented, one had hindquarter paralysis; a second was tetraplegic. Lesions in the central nervous system and an immature female worm were consistent with those of Parelaphostrongylus tenuis. The llamas had shared pastures with white-tailed deer.

75. BEAUDOIN, R.L., W.M. SAMUEL, and C.P.A. STROME. 1970. A comparative study of the parasites in two populations of white-tailed deer. Journal of Wildlife Diseases 6: 56-63.

Prevalences of $P$. tenuis in two populations of white-tailed deer in Pennsylvania were 30 and 76 per cent. In both populations there was an increase in prevalence with increase in host age.

76. BEELER, D.A., D.A. BENSON, and W.M. LANGVILLE. 1959. Mineral analyses of livers and kidneys of moose Alces americana. Journal of Wildlife Management 23: 356-358.

77. BEHREND, D.F. 1970. The nematode, Pneumostrongylus tenuis, in white-tailed deer in the Adirondacks. New York Fish and Game Journal 17: 45-49.

Meningeal worms were found in the cranial cavities of 72 per cent of 180 white-tailed deer from the Adirondack Mountain region of New York, USA. Prevalence and intensity were less in fawns than in yearlings or adults. Prevalence was similar in male and female deer. 
78. BEHREND, D.F., and J.F. WITTER. 1968.

Pneumostrongylus tenuis in white-tailed deer in Maine. Journal of Wildlife Management 32: 963-966.

Heads of 84 per cent of 196 white-tailed deer were infected with adult meningeal worm.

79. BENSON, D.A. 1952. Treatment of a sick moose with cobaltous chloride. Journal of Wildlife Management 16: 110-111.

80. BENSON, D.A. 1958. Moose "sickness" in Nova Scotia (I). Canadian Journal of Comparative Medicine 22: 244-248.

Studied 47 cases of unique disease, "moose sickness", in wild moose. Could not find the cause of disease.

81. BENSON, D.A. 1959. Moose "sickness" in Nova Scotia (II). Canadian Journal of Comparative Medicine 22: 282-286.

Histopathologic examination of above-mentioned cases. No organism or pathogen was isolated.

82. BENSON, D.A., and G.D. DODDS. 1977. The deer of Nova Scotia. Department of Lands and Forests, Nova scotia. 92pp.

Review the history of moose and white-tailed deer population changes and habitat changes.

83. BERGERUD, A.T., and W.E. MERCER. 1989. Caribou introductions in eastern North America. Wildlife Society Bulletin 17: 111-120.

Review 33 introductions of caribou into eastern North America; six failures occurred where white-tailed deer were common. Conclude that "caribou cannot be introduced to ranges where white-tailed deer have a high frequency of meningeal worm infection".

84. BINDERNAGEL, J.A., and R.C. ANDERSON. 1972.

Newer aspects of the problem of meningeal worm

(Pneumostrongylus tenuis) in North America:

Distribution in white-tailed deer and moose. North

American Moose Conference and Workshop 8: 1-17.

See next reference

85. BINDERNAGEL, J.A., and R.C. ANDERSON. 1972. Distribution of the meningeal worm in white-tailed deer in Canada. Journal of Wildlife Manangement 36: 1349-1353.

Document the distribution of $P$. tenuis in Nova Scotia, New Brunswick, Quebec, Ontario, Manitoba, and Saskatchewan based on published literature, first-stage larvae in deer feces $(n=1,450$ samples examined), and examination of 141 deer heads for adult worms. The westernmost record of adult $P$. tenuis occurred in a deer 50 kilometers east of the Manitoba-Saskatchewan border.

86. BLAIR, L.S., and T.R. KLEI. 1986. Nematode infections of domestic animals: Extraintestinal infections. In:

Campbell, W.C., and R.S. Rew (eds.), Chemotherapy of parasitic diseases, Plenum Press, New York, New York, pp. 307-319.

Mention papers by Prosl and Kutzer (1980) and Rehbinder et al. (1982) (both included below) who show that Fenbendazole and Mebendazole, respectively are efficacious against $E$. cervi and $E$. rangiferi, respectively.

87. BROWN, T.T., JR., H.E. JORDAN, and C.N. DEMOREST. 1978. Cerebrospinal parelaphostrongylosis in llamas. Journal of Wildlife Diseases 14: 441-444.

Four of 11 llamas from Texas developed clinical signs of a neurologic disease. Lesions in two of the four and an adult nematode lead to the conclusion that the disease was caused by meningeal worm.

88. CAHN, A.R., G.I. WALLACE, and L.J. THOMAS. 1932. A new disease of moose. III. Science 76: 385.

Describe a new bacterium, Klebsiella paralytica, as cause of "moose-tick disease" ("moose sickness").

89. CAMERON, A.W. 1949. Report on biological investigations of game and fur-bearing animals in Nova Scotia-1948. Report of the Nova Scotia Department of Lands and Forests. pp 5-28.

90. CARPENTER, J.W., H.E. JORDAN, and J.A. MORRISON. 1972. Meningeal worm (Parelaphostrongylus tenuis) infection in white-tailed deer in Oklahoma. Journal of Wildlife Diseases 8: 381-383.

Found meningeal worm in 52 per cent of 77 white-tailed deer in Oklahoma, USA.

91. CARPENTER, J.W., H.E. JORDAN, and B.C. WARD. 1973. Neurologic disease in wapiti naturally infected with meningeal worms. Journal of Wildlife Diseases 9: 148-153.

Describe lesions (and recovered mature and immature $P$. tenuis) from four elk showing clinical signs of neurologic disease. Owing to the recovery of an adult worm, authors speculate on the possibility that meningeal worm could become established in elk herds after an initial exposure in areas of overlap with infected white-tailed deer.

92. CHEATUM, E.L. 1948. A contribution to the life cycle of the lungworm, Leptostrongylus alpenae (Nematode: Metastrongylidae),with observations on its incidence and biology. Dissertation (Bibliofilm), Library of Congress, Washington, D.C.

(Owing to similarity of first-stage larvae of several nematodes of North American ruminants, it is possible, perhaps probable, that some of the data contained in this important document deal with $P$. tenuis.)

93. CHENEY, J.M. 1989. Parasitism in llamas. Veterinary Clinics of North America: Food Animal Practice 5: 217-225. 
Contains a short literature review related to meningeal worm and encephalomalacia in llamas. Local hemorrhage often causes death of the animals. Clinical signs include: head tilting, arching of the neck, incoordination, difficulty in getting up, and a gradual weight loss. Llamas have been treated with levamisole, diethycarbamazine, glucocorticoids, and vitamin B. Author recommends treating infected animals with ivermectin. States that some producers treat llamas monthly with ivermectin at $0.2 \mathrm{mg}$ per $\mathrm{kg}$ body weight to control new infections.

94. CLARK, R.A., and R.R. BOWYER. 1987. Occurrence of protostrongylid nematodes in sympatric populations of moose and white-tailed deer in Maine. Alces 23:

313-321.

Found spined larvae in 9.6 per cent of 594 moose fecal samples and 50 per cent of 104 deer fecals from Baxter State Park in winter, 1984. Suggest that larvae are those of $P$. tenuis and that moose may be developing a tolerance to meningeal worm. No attempts were made to recover adult worms.

95. CLARK, A.H., J.P. KELSALL, and G.R. PARKER. 1968. The landsnail fauna of Fundy National Park, New Brunswick. Bulletin of the National Museums of Canada, Number 223, 22 pp.

Twenty four species of terrestrial gastropods were identified in a study initiated because moose in the Park acquired neurologic disease attributed to meningeal worm.

96. COLE, G.F. 1981. Alternative hypotheses on ecological effects of meningeal parasite (Parelaphostrongylus tenuis). Journal of the Minnesota Academy of Science 47: 8-10.

Further qualifies statements that $P$. tenuis either does or does not prevent or restrict overlapping distributions of woodland caribou or moose with white-tailed deer. The hypothesis that $P$. tenuis allows deer to outcompete caribou or moose on portions of natural environments or in man-modified environments where deer densities are relatively high, appears to be consistent with published accounts of mortality caused by the parasite.

97. DAUPHINE, T.C., JR. 1975. The disappearance of caribou reintroduced to Cape Breton Highlands National Park. Canadian Field-Naturalist 89: 299-310.

Fifty-one Rangifer tarandus caribou from Quebec released in Cape Breton Park, Nova Scotia, Canada, in 1968-1969, disappeared by 1972. Losses were attributed to meningeal worm because the animals had reproduced, there was no evidence of starvation, poaching, predation, or emigration, and three caribou were observed with clinical neurologic signs.

98. DAVIDSON, W.R., J.M. CRUM, J.L. BLUE, D.W. SHARP, and J.H. PHILLIPS. 1985. Parasites, diseases, and health status of sympatric populations of fallow deer and white-tailed deer in Kentucky. Journal of Wildlife Diseases 21: 153-159.

Five wild free-ranging adult fallow deer, from a population that has coexisted with white-tailed deer in Kentucky since the 1920's, were examined for parasites and diseases. All five had inflammatory lesions in the spinal cord and/or brain that were attributed to prior infection with $P$. tenuis. The high rate of exposure with low rate of clinical disease in fallow deer was attributed to: 1) a low prevalence and intensity of $P$. tenuis in the area; 2 ) partial innate resistance of fallow deer; and 3) acquired immunity. The authors suggest that fallow deer are less vulnerable to $P$. tenuis than are other species such as moose and caribou.

99. DEGIUSTI, D.L. 1955. The occurrence of a protostrongylid nematode $\mathrm{i}$ the meninges of Michigan deer. Journal of Parasitology 41(2): 42 (abstract).

100. DEGIUSTI, D.L. 1963. Incidence and distribution of Elaphostrongylus odocoilei in Michigan deer herd. Journal of Parasitology 49 (Suppl.): 47.

A total of 56.5 per cent of 836 heads of white-tailed deer from throughout Michigan and examined between 1953 and 1962 were infected with $E$. odocoilei $(=P$. tenuis $)$.

101. DEVLIN, D., and W. DRAKE. 1989. Pennsylvania elk census - 1989. Annual Unpublished Report, Pennsylvania Game Commission, Harrisburg, Pennsylvania. 8 pp.

A population of 154 elk, the highest number since 1971, inhabited $500 \mathrm{~km}^{2}$ in the northcentral part of the state in 1989. Meningeal worm, thought to be a major mortality factor in the 1970's, accounted for 11 per cent of known mortalities since 1975 (and 1 case each in 1986, 1987, and 1988).

102. DEW, T.L. 1988. Prevalence of Parelaphostrongylus tenuis in a sample of hunter-harvested white-tailed deer from a tri-county area in northeastern Wisconsin. Journal of Wildlife Diseases 24: 720-721.

Seventy-eight per cent of 44 deer were infected with $P$. tenuis. There were no differences in prevalences when animals were grouped by sex or age ( $=$ or $<$ and $>2$ yrs).

103. DIKMANS, G., and E.E. WEHR. 1935. An unidentified nematode from the eye of the moose, Alces americana. Proceedings of the Helminthological Society Washington 2: 57 .

Describe immature female nematode, possibly Elaphostrongylus sp. (=P.tenuis), from eye of moose from Minnesota.

104. DOUGHERTY, E.C. 1945. The nematode lungworms (suborder Strongylina) of North American deer of the genus Odocoileus. Parasitology 36: 199-208.

Describes Pneumostrongylus tenuis based on a single male worm collected from the bronchiole of a white-tailed deer, Odocoileus virginianus from New York, USA, by Cheatum (see Cheatum, 1948). Redescribes and transfers Pneumostrongylus alpenae to Varestrongylus alpenae. Only record of adult $P$. tenuis in lung tissue.

105. DUDAK, D., G.W. CORNWELL, R.B. HOLLIMAN, and B.S. MCGINNES. 1965. The incidence and degree of infection of Pneumostrongylus tenuis in the white-tailed deer of western Virginia. Transactions of the Annual 
Conference of the Southeastern Association of the Game and Fish Commissioners, Tulsa, OK 19: 128-141.

Prevalence of 73 per cent is reported.

106. ECKROADE, R.J., G.M. ZURHEIN, M. GABRIELE, and W. FOREYT. 1970. Meningeal worm invasion of the brain of a naturally infected white-tailed deer. Journal of Wildlife Diseases 6: 430-436.

Case report from captive deer in Wisconsin, USA.

107. EKLUND, C.M., and W.J. HADLOW. 1978. Infections of the nervous system - Part II. In Vinken, P.J., Bruyn, G.W., and H.L. Klawans (eds.), Handbook of clinical neurology, North-Holland Publishing Co., Amsterdam, pp. 291-305.

108. EVELAND, J.F., J.L. GEORGE, N.V. HUNTER, D.M. FORNEY, and R.L. HARRISON. 1979. A preliminary evaluation of the ecology of the elk in Pennsylvania. In Boyce, M.S., and L.D. Hayden-Wing (eds.), North American elk: ecology, behavior and management. University of Wyoming, Laramie, WY, pp. 145-151.

109. FENSTERMACHER, R. 1934. Diseases affecting moose. The Alumni Quarterly (Minnesota) 22: 81-94.

110. FENSTERMACHER, R. 1934. Further studies of diseases affecting moose. University of Minnesota Agricultural Experiment Station Bulletin 308: 26pp.

Seven cases of "moose sickness" are reviewed. No conclusions are reached as to cause. Paper includes two photomicrographs of cross-sections of nematodes in the brain stem of a moose.

111. FENSTERMACHER, R. 1937. Further studies of diseases affecting moose.II. Cornell Veterinarian 27: 25-37.

Five cases of "moose sickness" are reviewed. A variety of parasites are documented for moose, but no conclusions are reached as to a causative agent.

112. FENSTERMACHER, R., and M.L. JELLISON. 1933.

Diseases affecting moose. University of Minnesota

Agricultural Experiment Station Bulletin 294: 20 pp.

Review 10-year history of their research into "moose sickness". Attention paid to winter ticks, Dermacentor albipictus.

113. FENSTERMACHER, R., and O.W. OLSEN. 1942. Further studies of diseases affecting moose. Cornell Veterinarian 32: $241-254$.

114. FOREYT, W.J. 1986. Recovery of nematode eggs and larvae in deer: evaluation of fecal preservation methods. Journal of the American Veterinary Medical Association 189(9): 1065-1067.

The number of first-stage larvae indistinguishable from those of $P$. tenuis recovered from fecal samples stored in 10 per cent formalin for 24 days was greater than that recovered from fresh fecal samples.
115. FOREYT, W.J., and D.O. TRAINER. 1980. Seasonal parasitism changes in two populations of white-tailed deer in Wisconsin. Journal of Wildlife Management 44: 758-764.

Examination of 30 fecal samples each month for one year from two sites in Wisconsin for selected parasites including larvae of "Parelaphostrongylus sp." resulted in total prevalences of 30.6 and 28.1 per cent, respectively. Prevalence was highest for one site from April through June and in the other in October.

116. GETZ, L.L. 1959. Notes on the ecology of slugs: Arion circumscriptus, Deroceras reticulatum, and D. laeve. American Midland Naturalist 61: 485-498.

117. GILBERT, F.F. 1973. Parelaphostrongylus tenuis (Dougherty) in Maine: 1 - The parasite in white-tailed deer (Odocoileus virginianus, Zimmermann). Journal of Wildlife Diseases 9: 136-143.

Annual prevalence in deer between 1968-1970 ranged from 63 to 80 per cent. Prevalence in fawns and males was significantly lower than in older deer and females, respectively. One area of relatively low deer density had the highest prevalence, while a region of relatively high deer density had the lowest. Locations of worms in the cranial cavity are described.

118. GILBERT, F.F. 1974. Parelaphostrongylus tenuis in Maine: II - Prevalence in moose. Journal of Wildlife Management 38: 42-46.

Found meningeal worm in 28 per cent of 153 moose (Alces alces) in Maine, USA. Average worm recovery from the cranial cavity was 1.9 and most worms were penetrating the neural parenchyma.

119. GLEICH, J.G., and F.F. GILBERT. 1976. A survey of terrestrial gastropods from central Maine. Canadian Journal of Zoology 54: 620-627.

120. GLEICH, J.G., F.F. GILBERT, and N.P. KUTSCHA. 1977. Nematodes in terrestrial gastropods from central Maine. Journal of Wildlife Diseases 13: 43-46.

Only four larvae of $P$. tenuis were found during examination of 1700 terrestrial gastropods.

121. GUTHERY, F.S., S.L. BEASOM, and L. JONES. 1979. Cerebrospinal nematodiasis caused by

Parelaphostrongylus tenuis in Angora goats in Texas. Journal of Wildlife Diseases 15: 37-47.

Twenty-eight of 206 adult Angora goats from eastern Texas developed neurologic disease attributable to $P$. tenuis. 17 died.

122. HAYES, F.A. 1965. Doe harvest needed for herd balance. South Carolina Wildlife, Winter issue.

123. HAYES, F.A., W.E. GREER, and E.B. SHOTTS. 1958. A progress report from the Southeastern Cooperative Deer Disease Study. Transactions of the North American Wildlife Conference 23: 133-136. 
124. HOLMES, J.C. 1982. Impact of infectious disease agents on the population growth and geographical distribution of animals. In: Anderson, R. M., and R. M. May (eds.), Population biology of infectious diseases Dahlem Konferenzen, Berlin, Heidelberg, New York: Springer-Verlag. pp. 37-51.

Discusses $P$. tenuis in the context of disease due to agents maintained in one species of host, but pathogenic in other species. Presents "weapon of competition" idea (see Barbehenn, 1969) wherein white-tailed deer with meningeal worm may be responsible for low populations of susceptible hosts such as moose in areas where host ranges overlap (or the parasite may even preclude such overlap).

125. INNES, J.R.M., and L.Z. SAUNDERS. 1962. Comparative Neuropathology. Academic Press, New York.

126. IRWIN, L.L. 1975. Deer-moose relationships on a burn in northeastern Minnesota. Journal of Wildlife Management 39: 653-662.

A five-fold increase in moose numbers, resulting from immigration, occurred in an area burned 1-2 years previously. This resulted in the suggestion that moose populations could increase despite the presence of deer with meningeal worm. The possibility that the fire reduced the gastropod intermediate hosts is suggested as one factor involved.

127. JORTNER, B.S., H.F. TROUTT, T. COLLINS, and K. SCARRATT. 1985. Lesions of spinal cord parelaphostrongylosis in sheep. Sequential changes following intramedullary larval migration. Veterinary Pathology 22: 137-140.

Spinal cords from two Suffolk sheep with active infection and one from a partially recovered animal in Virginia were studied to determine the sequence of lesions following invasion of the CNS by larval $P$. tenuis.

128. KARNS, P.D. 1966. Pneumostrongylus tenuis from elk (Cervus canadensis) in Minnesota. Bulletin of the Wildlife Disease Association 2: 79-80.

Found spined larvae in feces of wild elk and attributes them to meningeal worm. This is the first report of meningeal worm in wild elk, but no necropsies were done.

129. KARNS, P.D. 1967. Pneumostrongylus tenuis in deer in Minnesota and implications for moose. Journal of Wildlife Management 31: 299-303.

Prevalence of meningeal worm was 49 per cent based on examination of 140 deer heads. Prevalence was higher in central Minnesota where deer densities were high and lower in northern Minnesota where deer densities were low.

130. KARNS, P.D. 1977. Deer-moose relationships with emphasis on Parelaphostrongylus tenuis. Minnesota Wildlife Research Quarterly 37: 40-61.

131. KARNS, P.D. Survey of Parelaphostrongylus tenuis as a potential limiting factor to woodland caribou (Rangifer tarandus) in northern Minnesota. Unpublished Report, Minnesota Department of Natural Resources, Grand Rapids.

132. KARNS, P.D., and S.L. BARTON. 1967. A tiny invader and the mighty moose. Conservation Volunteer 30(176): 17-19.

133. KARNS, P.D., and P.A. JORDAN. 1969.

Pneumostrongylus tenuis in moose on a deer-free island. Journal of Wildlife Management 33: 431-433.

Report first-stage larvae in feces of 0.8 and 0.6 per cent of moose from Isle Royale, Michigan, USA (deer-free for 30 years) and northeastem Minnesota USA (where few deer lived). (Results are likely the result of contamination of equipment in the laboratory; see p. 470 of Lankester, 1987.)

134. KEARNEY, S.R., and F.F. GILBERT. 1976. Habitat use by white-tailed deer and moose on sympatric range. Journal of Wildlife Management 40: 645-657.

Found very little spatial overlap of moose and white-tailed deer in in summer in the Himsworth Game Preserve, central Ontario, Canada, when transmission of meningeal worm would be expected via accidental ingestion of infected terrestrial gastropods.

135. KEARNEY, S.R., and F.F. GILBERT. 1978. Terrestrial gastropods from the Himsworth Game Preserve, Ontario, and their significance in Parelaphostrongylus tenuis transmission. Canadian Journal of Zoology 56: 688-694.

Only 19 infective third-stage larvae of meningeal worm were found during digestions of 16,450 gastropods.

136. KELSALL, J.P., and W. PRESCOTT. 1971. Moose and deer behaviour in snow in Fundy National Park, New Brunswick. Report Series Canadian Wildlife Service, Number 15, 25 pp.

Authors contend that snow conditions resulted in moose being found at high elevations and deer at low elevations in Fundy National Park, Canada. They suggest that moose that migrated to lower elevations almost invariably died of neurologic disease caused by $P$. tenuis.

137. KENNEDY, P.C., J.H. WHITLOCK, and S.J. ROBERTS. 1952. Neurofilariosis, a paralytic disease of sheep. I. Introduction symptomatology and pathology. Cornell Veterinarian 42: 118-124.

First report of meningeal worm in the CNS of sheep, in this case from New York. Worms were designated as Neurofilaria cornellensis (see Whitlock, 1952).

138. KING, L.S. 1939. Moose encephalitis. American Journal of Pathology 15: 445-454.

Describes a subacute or chronic leukoencephalitis of unknown etiology.

139. KISTNER, T.P., G.R. JOHNSON, and G.A. RILLING. 1977. Naturally occurring neurologic disease in a fallow 
deer infected with meningeal worms. Journal of Wildlife Diseases 13: 55-58.

Neurologic disease attributable to meningeal worm is described from a clinically ill fallow deer, Dama dama, from Georgia, USA. Only immature worms were recovered.

140. KOCAN, A.A., M.G. SHAW, K.A. WALDRUP, and G.J. KUBAT. 1982. Distribution of Parelaphostrongylus tenuis (Nematoda: Metastrongyloidea) in white-tailed deer from Oklahoma. Journal of Wildlife Diseases 18: 457-460.

Thirty nine per cent of 190 whitetails from 23 counties of Oklahoma had $P$. tenuis. Infected deer were from southeastern mixed forest, oak-hickory forest, oak-blue stem parkland and oak-hickory parkland. Distribution and densities of snails and deer feeding habits are discussed.

141. KOCAN, A.A. 1985. The use of ivermectin in the treatment and prevention of infection with Parelaphostrongylus tenuis (Dougherty) (Nematoda: Metastrongyloidea) in white-tailed deer (Odocoileus virginianus Zimmermann). Journal of Wildlife Diseases 21: 454-455.

Results of a study using captive deer given ivermectin at a dosage of $0.1 \mathrm{mg} / \mathrm{kg}$ body weight indicated that the drug did not have a practical application for the elimination or prevention of $P$. tenuis infections.

142. KOPCHA, M. 1988. Parasitic infection of the nervous system. National Wool Grower Magazine, March Issue, pp. 32-33.

A brief review of $P$. tenuis infection with emphasis on sheep and goats. Includes a partial list of the diseases with symptoms like that of $P$. tenuis in sheep or goats. These are: listeriosis, caprine arthritis-encephalitis, polioencephalo-malacia, scrapie, nutritious deficiencies, trauma, tail-docking infection, brain or spinal cord abscess, and rabies.

143. KOPCHA, M, J.V. MARTENIUK, R. SILLS, B. STEFICEK, and T.W. SCHILLHORN VAN VEEN. 1989. Cerebrospinal nematodiasis in a goat herd. Journal of the American Veterinary and Medical Association 194:1439-1442.

Four of 40 Angora goats in Michigan developed clinical signs of a neurologic disease. Lesions and identification of larval $P$. tenuis in section of nervous tissue lead to the conclusion that the disease was caused by meningeal worm.

144. KRADEL, D.C., and H.W. DUNNE. 1964. Diseases of the brain and spinal cord observed in Pennsylvania deer and other wildlife. Northeast Wildlife Conference, Hartford, Connecticut January 21, $7 \mathrm{pp}$ (mimeo).

145. KROGDAHL, D.W., J.P. THILSTED, and S.K. OLSEN. 1987. Ataxia and hypermetria caused by Parelaphostrongylus tenuis infection in llamas. Journal of the American Veterinary and Medical Association 190:191-193.

Three of seven llamas transported from Virginia to New Mexico became ataxic shortly after delivery. Lesions and worms were consistent with $P$. tenuis. The herd was treated with ivermectin at $200 \mu \mathrm{g} / \mathrm{kg}$ body wt once a month for 6 months and the neurologic signs in two affected llamas gradually subsided. Recovery may have been spontaneous and not related to treatment with ivermectin.

146. KURTZ, H.J., K. LOKEN, and J.C. SCHLOTTHAUER. 1966. Histopathologic studies on cerebrospinal nematodiasis of moose in Minnesota naturally infected with Pneumostrongylus tenuis. American Journal of Veterinary Research 27: 548-558.

Found eggs, larvae and adult $P$. tenuis in brains of 17 wild moose with clinical signs of neurologic disease. Histopathologic lesions are described.

147. LANKESTER, M.W. 1974. Parelaphostrongylus tenuis (Nematoda) and Fascioloides magna (Trematoda) in moose of southeastern Manitoba. Canadian Journal of Zoology 52: 235-239.

Ten moose had clinical signs indicating neurologic damage; nine heads were examined and adult $P$. tenuis were found in three. Lesions are described.

148. LANKESTER, M.W. 1987. Pests, parasites and diseases of moose (Alces alces) in North America. Swedish Wildlife Research Viltrevy, Supplement 1, Part 2:461-489.

Reviews the last 10 years of published information on $P$. tenuis.

14. LANKESTER, M.W. and D. FONG. 1989. Distribution of elaphostrongyline nematodes (Metastronglyoidea: Protostrongylidae) in cervidae and possible effects of moving Rangifer spp. into and within North America. Alces 25: 133-145.

See this referenc under Elaphostrongylus spp.

149. LANKESTER, M.W., and R.C. ANDERSON. 1968. Gastropods as intermediate hosts of Pneumostrongylus tenuis Dougherty of white-tailed deer. Canadian Journal of Zoology 46: 373-383.

Deroceras laeve (a slug) and Zonitoides nitidus (a snail) were the species most abundant and commonly infected with meningeal worm larvae on an island in southern Ontario, Canada. A wet forested habitat where gastropods were abundant, commonly infected, and active from May to October was felt to be a major area for transmission. Larvae were found in mucous that covered fecal pellets. Snails could be reinfected and larvae on feces survived freezing at -15 to $-20^{\circ} \mathrm{C}$ for up to 300 days.

150. LEVINE, N.D. 1968. Nematode parasites of domestic animals and of man. Burgess Publishing Company, Minneapolis MN. 600pp. 
Mentions ( $p .287)$ that spine-tailed larvae like that of meningeal worm were found in feces of about one-half of several hundred white-tailed deer from Illinois.

151. LOKEN, K.I., J.C. SCHLOTTHAUER, P.D. KARNS, and M.J. GRIFFITHS. 1964. Studies on moose "disease" in Minnesota. Great Lakes Deer Symposium (unpub. mimeo.)

152. LOKEN, K.I., J.C. SCHLOTTHAUER, H.J. KURTZ, and P.D. KARNS. 1965. Pneumostrongylus tenuis in Minnesota moose (Alces alces). Wildlife Disease Association Bulletin 1: 7.

Examined 18 moose with neurologic disease. Found meningeal worm in eight and larvae believed to be those of meningeal worm in feces of one moose.

153. LUNN, D.K., and K.W. HINCHCLIFF. 1989.

Cerebrospinal fluid eosinophilia and ataxia in five llamas. Veterinary Record 124: 302-305.

Cerebrospinal fluid eosinophilia was associated with ataxia in five llamas from Wisconsin. A presumptive diagnosis of cerebrospinal parasitism was made and all animals responded to combined anthelmintic and anti-inflammatory therapy. Treatment consisted of subcutaneous ivermectin $(200 \mu \mathrm{g} / \mathrm{kg}$, one treatment $)$, oral fenbendazole ( $30 \mathrm{mg} / \mathrm{kg}$, once daily for 5 days), and intramuscular flunixine meglumine $(1 \mathrm{mg} / \mathrm{kg}$, twice daily for 5 days.

154. MAYHEW, I.G., A. DELAHUNTA, J.R. GEORGI, and D.G. ASPROS. 1976. Naturally occurring cerebrospinal parelaphostrongylosis. Cornell Veterinarian 66: 56-72.

One isolated case and an outbreak of 10 cases of neurologic disease attributed to meningeal worm are described from goats on two farms in New York State, USA.

155. MAZE, R.J., and C. JOHNSTONE. 1986. Gastropod intermediate hosts of the meningeal worm

Parelaphostrongylus tenuis in Pennsylvania: observations on their ecology. Canadian Journal of Zoology 64: 185-188.

Sixteen per cent of 445 snails from a small area in northcentral Pennsylvania, where a small free-ranging population of wild elk occurs, had larvae of $P$. tenuis. New intermediate hosts were Triodopsis albolabris, $T$. tridentata and Ventridens intertextus. The only slug infected was Deroceras laeve. An old reclaimed strip mine contained most of the snails (81\%) and infected snails (92\%).

156. NEILSEN, S.W., and J. AFTOSMIS. 1964. Spinal nematodiasis in two sheep. Journal of the American Veterinary Medical Association 144: 155-158.

Case reports of two Suffolk sheep from Connecticut with severe spinal meningomyelitis and posterior paresis are described. $P$. tenuis was found in the lumbar region of the spinal cord of one animal.

157. NETTLES, V.F., and A.K. PRESTWOOD. 1979. Experimental infection of rabbits with meningeal worm. Journal of Parasitology 65: 327-328.
Six domestic rabbits, Oryctolagus cuniculus, 10 cottontail rabbits, Sylvilagus floridanus, and one swamp rabbit, S. aquaticus, were given larvae of $P$. tenuis. No neurological abnormalities were observed. Presence of Nosema cuniculi and larval Taenia pisiformis made interpretation of host tissue response difficult. Only one viable $P$. tenuis was found during histological examination, that in a rabbit killed 42 days after infection.

158. NETTLES, V.F., A.K. PRESTWOOD, R.G. NICHOLS, and C.J. WHITEHEAD. 1977. Meningeal worm-induced neurologic disease in black-tailed deer. Journal of Wildlife Diseases 13: 137-143.

$P$. tenuis was considered the cause of an unsuccessful translocation of black-tailed deer, Odocoileus hemionus columbianus, from Oregon to Tennessee, USA. Clinical and pathologic findings are described.

159. NETTLES, V.F., A.K. PRESTWOOD, and R.D. SMITH. 1977. Cerebrospinal parelaphostrongylosis in fallow deer. Journal of Wildlife Diseases 13: 440-444.

Clinical signs, gross and microscopic cerebrospinal lesions are described from seven fallow deer, Dama dama, from the Land Between The Lakes region of Kentucky, USA. All were attributable to meningeal worm. Degenerating or immature worms were recovered from the nervous system of six deer.

160. NICHOLS, D.K., R.J. MONTALI, M. BUSH, L. PHILLIPS, and L. COLLINS. 1986. Parelaphostrongylus tenuis infections in captive exotic ungulates. Proceedings of the Annual Meeting of the American Association of Zoo Veterinarians: 27-28.

Reports $P$. tenuis in six reindeer, Rangifer $t$. tarandus, two Sable antelope, Hippotragus niger, two Scimitar oryx, Oryx dammak (presumptive) and one Bongo, Tragelaphus eurycerus (presumptive) at the National Zoological Park's Conservation and Research Centre, Front Royal, Virginia, USA. Clinical signs and necropsy findings are described. Treatment of three reindeer with dexamethasone at 1 $\mathrm{mg} / \mathrm{kg}$ body weight intravenous and levamisole at $5.5-11 \mathrm{mg} / \mathrm{kg}$ subcutaneous and of one $H$. niger with dexamethasone and ivermectin at $0.6 \mathrm{mg} / \mathrm{kg}$ intramuscular gave initial mild improvement, but eventually all animals died.

161. NICHOLS, D.K., R.J. MONTALI, L.G. PHILLIPS, T.P. ALVARADO, M. BUSH, and L. COLLINS. 1986.

Parelaphostrongylus tenuis in captive reindeer and sable antelope. Journal of the American Veterinary and Medical Association 188: 619-621.

See previous reference.

162. NUDDS, T.D. 1990. Retroductive logic in retrospect: The ecological effects of meningeal worms. Journal of Wildlife Management 54: 396-402.

Reviews two widely accepted hypotheses: 1) that meningeal worms of white-tailed deer cause population declines in moose, and 2) if moose populations remain viable in areas where meningeal worm is present in deer, it is because moose reside in habitat refuges. Concludes that no data have been presented to test the first hypothesis and available data do not support the second hypothesis. 
163. O'BRIEN, T.D., T.P. O'LEARY, J.R. SHERMAN, D.L. STEVENS, and C.B. WOLF. 1986. Cerebrospinal parelaphostrongylosis in Minnesota. Minnesota Veterinarian 26: 18-22.

Record the clinical and pathological features of $P$. tenuis in two llamas and one sheep in Minnesota, USA.

164. OLSEN, A., and A. WOOLF. 1978. The development of clinical signs and the population significance of neurological disease in a captive wapiti herd. Journal of Wildlife Diseases 14: 263-268.

Describe the kind and sequence of clinical signs of six elk, Cervus elaphus canadensis, held in a very large enclosure in Pennsylvania, with natural infections of $P$. tenuis. The mean time between initial sign observed and death was 100 days. Data presented lead to suggestion that meningeal worm causes significant mortality in the younger age classes of wapiti.

165. OLSEN, A., and A. WOOLF. 1979. A summary of the prevalence of Parelaphostrongylus tenuis in a captive wapiti population. Journal of Wildlife Diseases 15: 33-35.

Annual prevalence of $P$. tenuis was determined by necropsy of wapiti from 1973-1977. Prevalence ranged from 27 to 64 per cent.

166. OLSEN, O.W., and R. FENSTERMACHER. 1943. The helminths of North American deer with special reference to those of the white-tailed deer (Odocoileus virginianus borealis) in Minnesota. University of Minnesota Agricultural Experiment Station Technical Bulletin 159: 20 .

167. PETERSON, R.L. 1955. North American Moose. University of Toronto Press, Toronto.

168. PETERSON, R.L. 1956. Ontario's big game. The deer family. Publication of the Royal Ontario Museum, Toronto, p. 16.

169. PETERSON, W.J. 1989. Abnormal antlers and kidney stones in moose displaying symptoms of parelaphostrongylosis. Alces 25: 11-14.

Two wild moose with symptoms compatible with parelaphostrongylosis, had abnormal antlers and many kidney stones. No stones were found in 56 other moose 12 of which had signs of neurologic disease. Author suggests that abnormal behavior during disease results in antler damage during velvet stage of growth.

16. PLATT, T.R. 1984. Evolution of the Elaphostrongylinae (Nematoda: Metastrongyloidea: Protostrongylidae) parasites of cervids (Mammalia). Proceedings of the Helminthological Society Washington 51: 196-204.

Evaluates the phylogenetic relationships of the Elaphostrongylinae by cladistic analysis. Elaphostrongylus cervi is considered the most ancestral member of the subfamily, while $P$. tenuis is the most ancestral member of the genus. $E$. cervi originated in the nearctic, cospeciating with Rangifer. Suggests that $P$. tenuis is not found in western North America because of lowered ability of $P$. tenuis larvae to infect gastropods following exposure to freezing conditions, compared to $P$.odocoilei larvae.

170. PLATT, T.R. 1989. Gastropod intermediate hosts of Parelaphostrongylus tenuis (Nematoda:

Matastrongyloidea) from northwestern Indiana. Journal of Parasitology 75: 519-523.

Found three species (Discus cronkhitei, Deroceras laeve and Cochlicopa $(=$ Cionella $)$ spp.) of gastropods infected with meningeal worm larvae. First report of $P$. tenuis from Indiana.

171. PRESCOTT, W.H. 1974. Interrelationships of moose and deer of the genus Odocoileus. le Naturaliste Canadien 101: 493-504.

States that meningeal worm has had more effect on eastern North American moose populations than any other factor.

172. PRESTWOOD, A.K. 1970. Neurologic disease in a white-tailed deer massively infected with meningeal worm (Pneumostrongylus tenuis). Journal of Wildlife Diseases 6: 84-86.

Documents clinical neurologic disease in an wild adult white-tailed deer in Georgia, USA. Signs observed were attributed to circulatory abnormality caused by the large masses of worms interfering with blood flow.

173. PRESTWOOD, A.K., and J.F. SMITH. 1969. Distribution of meningeal worm (Pneumostrongylus tenuis) in deer in the southeastern United States. Journal of Parasitology 55: 720-725.

The meninges of 50 per cent of a large sample of white-tailed deer from throughout the southeastern United States were infected with meningeal worm. Prevalence was higher in deer from mixed forest areas rather than sandy-soiled coniferous areas.

19. PRESTWOOD, A.K., V.F. NETTLES, and F.E. KELLOGG. 1974. Distribution of muscle worm, (Parelaphostrongylus andersoni), among white-tailed deer of the southeastern United States. Journal of Wildlife Diseases 10: 404-409.

P. tenuis was found in whitetails of Arkansas, Georgia, Maryland, North Carolina, Virginia and West Virginia.

174. PRICE, P.W., M. WESTOBY, and B. RICE. 1988. Parasite-mediated competition: some predictions and tests. The American Naturalist 131: 544-555.

Use meningeal worm as a test of their "geographic-range" hypothesis wherein wide-ranging hosts (white-tailed deer, also called "the winner") tend to displace species with a narrower range (moose the "loser") when a parasite common to both has differential impact.

175. PYBUS, M.J., W.M. SAMUEL, and V. CRICHTON. 1989. Identification of dorsal spined larvae from free-ranging wapiti (Cervus elaphus) in southwestern Manitoba, Canada. Journal of Wildlife Diseases 25: 291-293. 
Larvae from elk feces from southwestern Manitoba were passaged through snails and two captive whitetail fawns. Adult $P$. tenuis were recovered.

176. ROWLEY, M.A., E.S. LOKER, J.F. PAGELS, and R.J. MONTALI. 1987. Terrestrial gastropod hosts of Parelaphostrongylus tenuis at the National Zoological Park's Conservation and Research Center, Virginia. Journal of Parasitology 73: 1084-1089.

Found $P$. tenuis in 5 of 18 species of gastropods collected. Overall prevalence was 2.2 per cent and new host records were Ventridens collisella and Philomycus carolinianus. Other hosts were Deroceras laeve, Triodopsis tridentata and Zonitoides arboreus.

177. SAMUEL, W.M. 1968. Endoparasites of domestic ruminants and white-tailed deer. Transactions of the North American Wildlife Conference 33: 364-372.

Brief review of prevalence of $P$. tenuis in white-tailed deer and neurologic disease in domestic sheep.

178. SAMUEL, W.M. 1969. Parasites of the white-tailed deer in south Texas. Ph.D. Thesis, University of Wisconsin, Madison. 196pp.

No meningeal worms were found during examination of 56 heads of white-tailed deer from the Welder Wildlife Foundation Refuge, south Texas.

179. SAMUEL, W.M. 1987. Moving the zoo or the potential introduction of a dangerous parasite into Alberta with its translocated host. In: Renecker, L.A.(ed.) Focus on a New Industry. Proceedings of the Alberta Game Growers' Association Conference 1: 85-92

Reviews the potential for introducing and establishing meningeal worm with ungulate hosts translocated into Alberta by game growers.

180. SAMUEL, W.M., and R.L. BEAUDOIN. 1965.

Identification of eggs and larvae of nematodes parasitic in deer in Pennsylvania. Proceedings of the Pennsylvania Academy of Science 39: 73-77.

Provides key to nematode eggs and larvae encountered in feces of white-tailed deer of Pennsylvania.

181. SAMUEL, W.M., and R.L. BEAUDOIN. 1966. Evaluation of two survey methods for detection of helminth infections in white-tailed deer (Odocoileus virginianus). Wildlife Disease Association Bulletin 2: 100-107.

Compare efficiency of necropsy for adult worms with a technique that recovers worm eggs/larvae using a sugar flotation medium. Prevalence of $P$. tenuis was 75 per cent based on necropsy alone and 81 per cent when both necropsy and flotation procedures were used.

182. SAMUEL, W.M., and J.C. HOLMES. 1974. Search for elaphostrongyline parasites in cervids from Alberta. Canadian Journal of Zoology 52: 401-403.
Found no meningeal worm in cranial cavities of 140 white-tailed deer (Odocoileus virginianus), 20 mule deer ( $O$. hemionus hemionus) and 37 moose (Alces alces), but did find Parelaphostrongylus-like larvae in feces of mule deer of western Alberta. Suggest that these larvae are not those of Parelaphostrongylus tenuis (see Platt and Samuel, 1978).

183. SAMUEL, W.M., and D.O. TRAINER. 1969. A technique for survey of some helminth and protozoan infections of white-tailed deer. Journal of Wildlife Management 33: 888-894.

Found larvae indistinguishable from those of $P$. tenuis in feces of 15 per cent of 681 fecal samples from 24 counties in Wisconsin using a sugar flotation technique. Adult P. tenuis were recovered from the crania of 13 of 34 white-tailed deer.

184. SAUNDERS, B.P. 1973. Meningeal worm in white-tailed deer in northwestern Ontario and moose population densities. Journal of Wildlife Management 37: 327-330.

Infection of deer feces with larvae assumed to be those of P.tenuis was inversely proportional to population densities of moose. Found first-stage larvae of $P$. tenuis in 47 per cent of 603 fecal pellet groups of white-tailed deer.

185. SEGELQUIST, C.A., F.D. WARD, and R.G. LEONARD. 1969. Habitat-deer relations in two Ozark enclosures. Journal of Wildlife Management 33: 511-520.

Attributed two years of severe over-winter mortality of white- tailed deer in an enclosed area to nutritional deficiencies, extensive pulmonary damage due to presence of meningeal worm larvae, and exhaustion and respiratory complications following chases by dogs.

186. SHOESMITH, M.W. 1976. Mule Deer. The true jumpers of Manitoba. Department of Natural Resources, Information Series Number 13.15pp.

Discusses replacement of mule deer, Odocoileus hemionus, by white-tailed deer, O. virginianus, in southern Manitoba in last 75 years. Briefly considers that meningeal worm in whitetails might be a factor in loss of mule deer and states that "parasitologists do not believe that the original whitetail invaders were infected with this parasite and it has only been in the past 25 years that meningeal worm has gradually spread from east to west across southern Manitoba in established whitetail herds."

40. SHOSTAK, A.W., and W.M. SAMUEL. 1984. Moisture and temperature effects of survival and infectivity of first-stage larvae of Parelaphostrongylus odocoile $i$ and $P$. tenuis (Nematoda: Metastrongyloidea). Journal of Parasitology 70: 261-269.

See same reference in $P$. odocoilei section.

187. SMITH, H.J., and R.M. ARCHIBALD. 1967. Moose sickness, a neurological disease of moose infected with the com on cervine parasite, Elaphostrongylus tenuis. Canadian Veterinary Journal 8: 173-177.

Found $P$. tenuis in 80 per cent of 39 clinically ill moose and 6 per cent of 80 clinically normal moose. Sixty three per cent of 46 
white-tailed deer from the same area were infected and two of these were considered to be clinically ill.

188. SMITH, H.J., R.M. ARCHIBALD, and A.H. CORNER. 1964. Elaphostrongylosis in maritime moose and deer. Canadian Veterinary Journal 5: 287-296.

Recovered adult $P$. tenuis from 9 of 11 deer (mean number 4.5 ) and four of nine clinically ill moose (mean number 2.5) from Nova Scotia and New Brunswick. Also report larvae in the brain. A deer exhibited clinical signs of disease.

189. SMITH, J.F. 1972. A device to aid in examining the brain and meninges of deer for helminth parasites. Journal of Wildlife Diseases 8: 109-111.

190. SPRATT, D.M., and R.C. ANDERSON. 1968. The guinea pig as an experimental host of the meningeal worm, Pneumostrongylus tenuis Dougherty. Journal of Helminthology 42: 139-156.

Migration of larvae is documented over time, but few worms were found in the central nervous system. Five of 20 guinea pigs showed clinical signs.

191. SPRENT, J.G.A. 1955. On the invasion of the central nervous system by nematodes. I. The incidence and pathological significance of nematodes in the central nervous system. Parasitology 45: 31.

192. STACKHOUSE, L.L. 1977. Cerebral nematodiasis in two New Hampshire moose. Journal of the American Veterinary and Medical Association 171: 987-988.

Two cases of cerebral nematodiasis in moose, Alces alces, are described and attributed to $P$. tenuis.

193. TELFER, E.S. 1965. Some factors in the ecology of moose and white-tailed deer in Nova Scotia. Northeast Wildlife Conference, Harrisburg, Pennsylvania (16 page unpublished mimeograph).

194. TELFER, E.S. 1967. Comparison of moose and deer winter range in Nova Scotia. Journal of Wildlife Management $31: 418-425$.

Reviews how decrease in moose numbers after 1940 was paralleled by increase in numbers of white-tailed deer. $P$. tenuis is the suggested reason. Moose populations remained high in uplands where snow depth separated deer and moose.

195. TELFER, E.S. 1970. Winter habitat selection by moose and white-tailed deer. Journal of Wildlife Management 34: 553-559.

Probably owing to increasing snow depths overwinter, white-tailed deer and moose in the central New Brunswick lowlands were essentially exclusive in their use of habitat by March.

196. THOMAS, J.E., and D.G. DODDS. 1988. Brainworm, Parelaphostrongylus tenuis, in moose, Alces alces, and white-tailed Deer, Odocoileus virginianus, of Nova Scotia. Canadian Field-Naturalist 102: 639-642.

Found $P$. tenuis in heads 51 per cent of 213 white-tailed deer from throughout the province; prevalence of worms in moose heads was 6.5 per cent of 92 . Found spine-tailed first-stage larvae in 65 per cent of 535 deer fecal samples and 13 per cent of 318 moose fecal samples. Assumed larvae were those of meningeal worm because, although "larvae can only be positively identified to genus, $P$. tenuis is currently the only known species to occur in Nova Scotia or eastern Canada." (However, see Lankester and Northcott (1979) and Lankester and Hauta (1989).)

197. THOMAS, L.J., and A.R. CAHN. 1932. A new disease of moose. I. Preliminary report. Journal of Parasitology 18: 219-231.

198. THURSTON, D.R., and R.G. STROUT. 1978. Prevalence of meningeal worm (Parelaphostrongylus tenuis) in white-tailed deer from New Hampshire. Journal of Wildlife Diseases 14: 89-96.

Heads of 62 per cent of 127 white-tailed deer had meningeal worms. Prevalence of infection was higher in fawns and male deer. Locations of worms are provided.

199. TRAINER, D.O. 1973. Caribou mortality due to the meningeal worm (Parelaphostrongylus tenuis). Journal of Wildlife Diseases 9: 376-378.

Fourteen caribou, Rangifer tarandus terraenovae, reared in a game farm in Wisconsin were put into an area containing white-tailed deer and elk in mid-June. By late August and September 7 had die and were found to be infected with $P$. tenuis. All caribou were dead by January.

200. TYLER, G.V., C.P. HIBLER, and A.K. PRESTWOOD. 1980. Experimental infection of mule deer with Parelaphostrongylus tenuis. Journal of Wildlife Diseases 16: $533-540$

Neurologic disease was produced in 5 of 6 adult and all 3 fawn mule deer, Odocoileus hemionus given 75 to 100 infective larvae of $P$. tenuis. Cranial hemorrhage was seen in fawns but not in the adults. No larvae were recovered from feces.

201. UPSHALL, S.M., M.D.B. BURT, and T.G. DILWORTH. 1986. Parelaphostrongylus tenuis in New Brunswick:

The parasite in terrestrial gastropods. Journal of Wildlife Diseases 22:582-585.

Three of 14 species, Deroceras laeve, Zonitoides arboreus andDiscus cronkhitei, from three habitat sites in New Brunswick were infected with larvae of $P$. tenuis.

202. UPSHALL, S.M., M.D.B. BURT, and T.G. DILWORTH. 1987. Parelaphostrongylus tenuis in New Brunswick: the parasite in white-tailed deer (Odocoileus virginianus) and moose (Alces alces). Journal of Wildlife Diseases 23: 683-685.

Sixty per cent of 60 deer heads were infected with adult meningeal worm and 49 per cent of 91 fecal samples of white-tailed deer, and 0 
of 61 moose fecal samples were infected with larvae indistinguishable from those of meningeal worm.

203. WALLACE, G.I., A.R. CAHN, and L.J. THOMAS. 1933. Kiebsiella paralytica, a new pathogenic bacterium from "moose disease". Journal of Infectious Diseases 53:

386-414.

Note the coincidence of the appearance of "moose sickness" cases and high numbers of the winter tick, Dermacentor albipictus. Ticks from diseased moose, when placed on guinea pigs and rabbits, produced clinical signs similar to those exhibited by diseased moose. Isolated Klebsiella paralytica.

204. WALLACE, G.I., L.J. THOMAS, and A.R. CAHN. 1932. A new disease of moose. II. Proceedings of the Society of Experimental Biology and Medicine 29: 1098-1100.

205. WHITLOCK, J.H. 1952. Neurofilariosis, a paralytic disease of sheep: II. Neurofilaria cornellensis, n.g., n.sp. (Nematoda, Filarioidea), a new nematode parasite from the spinal cord of sheep. Cornell Veterinarian 42: 125-132.

(Later shown to be meningeal worm, Parelaphostrongylus tenuis.)

206. WHITLOCK, J.H. 1959. Elaphostrongylus, the proper designation of Neurofilaria. Cornell Veterinarian 49: $3-14$.

Transfers Neurofilaria cornellensis to Elaphostrongylus tenuis.

207. WHITLOCK, J.H. 1969. Review of reviews. (mimeograph), $15 \mathrm{pp}$.

An unpublished review of the scientific names given meningeal worm; also assesses Anderson's 1968 article in Helminthological Abstracts.

18. WOOLF, A., C.A. Mason, and D. Kradel. 1977. Prevalence and effects of Parelaphostrongylus tenuis in a captive wapiti population. Journal of Wildlife Diseases 13: 149-154.

Eight of 44 elk, Cervus elaphus canadensis, from the Rachelwood Preserve in western Pennsylvania had $P$. tenuis (1973-1975). Suggest that elk living close to whitetails may hava a high prevalence of infection, but many individuals may not show clinical signs. Also suggest that the apparent greater susceptibility of the younger age-classes to the parasite would have a detrimental effect on population recruitment and might limit growth of elk herds whose range overlap those of infected white-tailed deer. 


\section{ELAPHOSTRONGYLUS SPP.}

209. ANDERSEN, J., and O. HALVORSEN. 1984. Species composition, abundance, habitat requirements and regional distribution of terrestrial gastropods in Arctic Norway. Polar Biology 3: 45-53.

See Halvorsen, 1986.

210. ANDREEVA, N.K. 1958. (Atlas of helminths (Strongylata) of domestic and wild ruminants of Kazakhstan). Veterinary Institute of the Kazakh Section of Vaskhnil. 207 pp.

Russian text; english translation available from the United States Department of Commerce, National Technical Information Service, Springfield, Virginia 22161.

211. BAKKEN, G., and O. SPARBOE. 1973. (Elaphostrongylosis in reindeer). Nordisk Veterinaermedicin 25: 203-210.

Elaphostrongylus rangiferi is reported from the muscles of seven and the brain of 11 of 19 wild and domestic Rangifer tarandus tarandus from northern Norway. Indicate that parasite kills calves.

212. BAKKEN, G., O. SELLE, O. SPARBOE, and T. SOLHOY. 1975. Experimental Elaphostrongylus rangiferi infection in calves and lambs. Nordisk Veterinaermedicin 27: 220-223.

No clinical signs were observed in two sheep lambs (2-5 months old) and two cattle calves (3-4 weeks old) infected experimentally with between 40 and 95 third-stage larvae of $E$. rangiferi, but microscopic lesions similar to those in infected reindeer were found in the brain and spinal cord. No parasites were found. Lesions were attributed to migrating larvae.

213. BARUS, V., and K. BLAZEK. 1973. Report on the finding of larval nematodes Elaphostrongylus cervi (Protostrongylidae) in the cranial cavity of a stag. Folia Parasitologia 20: 279-280.

Found first-stage stage larvae of $E$. cérvi in ths cranial cavity of a young Cervus elaphus in Czechoslovakia.

214. BERGERUD, A.T. 1971. The population dynamics of Newfoundland caribou. Wildlife Monograph Number 25, $55 \mathrm{pp}$.

Report "Elaphostrongylus sp." and "Pneumostrongylus sp." in 7 of 14 caribou of Newfoundland, Canada. (Likely all worms were those of $E$. cervi (see Lankester and Northcott, 1979))

215. BLAZEK, K. 1976. (Some cerebrospinal diseases of red deer in Central Europe). Verhandlungsbericht des XVIII. Internationalen Symposiums uber die Erkrankungen der Zootiere, 16-20 June, 1976, Innsbruck, Germany; Akademie-Verlag, Berlin. 235-237.
Setaria was found in the subdural space of the brain and spinal cord and also in the ventricles of 4 of 40 red deer, Cervus elaphus hippelaphus. Elaphostrongylus cervi was found in five animals three of which had worms in the brain, associated with the sciatic nerve, and at the base of the brain with many larvae in the nasal passages, apparently having migrated through the lamina cribrosa.

216. BLAZEK, K., and I. DYKOVA. 1969. The pathological picture of some cerebrospinal disorders in red deer. Veterinarni Medicina (Praha) 14: 435-440.

The central nervous system of 32 red deer, nine of which showed clinical signs of a neurologic disease, were examined. One case of elaphostrongylosis is described.

217. BURG, W.B., E.A. BAUDET, and J.H. VERWEY. 1953. Lethal bleeding in the cranial cavity of deer (Cervus elaphus) caused by a nematode belonging to the family Metastrongylidae. Proceedings of the 15th International Veterinary Congress, Stockholm, vol. 1: 414-416.

Identified Protostrongyloides cervi (most likely Elaphostrongylus cervi) in Cervus elaphus in Holland.

218. BYE, K., and O. HALVORSEN. 1984. Isolation of Elaphostrongylus rangiferi from wild reindeer in Scandinavia. Veterinary Record 115: 87.

Recovered two adult worms from reindeer they believed was killed by $E$. cervi.

219. CAMERON, T.W.M. 1931. On two new species of nematodes from the Scottish red deer. Journal of Helminthology 9: 213-216.

Elaphostrongylus cervi described from red deer, Cervus elaphus, in Scotland.

220. DEMIASZKIEWICZ, A.W. 1985. (Elaphostrongylosis - a new parasitic disease of Cervidae in Poland). Medycyna Weterynaryjna 41: 616-618.

Elaphostrongylus cervi was found in carcasses of 32 of 224 red deer (Cervus elaphus), 0 of 92 roe deer (Capreolus capreolus), and 0 of 12 fallow deer (Dama dama), examined in a game meat factory. Most worms were associated with musculature, not the CNS.

221. DEMIASZKIEWICZ, A.W. 1986. (Laboratory diagnosis of protostrongylid infections in Cervidae). Medycyna Weterynaryjna 42: 660-663.

Morphology of first and third-stage larvae of Elaphostrongylus cervi and two species of Varestrongylus are compared. Species are differentiated on the basis of dimensions and shapes of the posterior part of their bodies.

222. DEMIASZKIEWICZ, A.W. 1987. (Species composition and prevalence of protostrongylid nematode infection in 
cervids on selected hunting grounds). Wiadomosci

Parazytologiczne 33: 57-62.

Checked feces of 190 roe deer, 409 red deer and 69 moose in Poland for protostrongylid larvae. Found larvae of Elaphostrongylus cervi in 78.5 and 4.3 per cent of red deer and moose, respectively, and Varestrongylus sagittatus in 27.6 per cent of the roe deer and $V$. capreoli in 33.7 and 23.2 per cent of red deer and moose, respectively.

223. DEMIASZKIEWICZ, A.W. 1987. Elaphostrongylus cervi Cameron, 1931 in European red deer (Cervus elaphus) in Poland. Acta Parasitologica Polonica 32: 171-178.

First report of $E$. cervi from Poland (host: $C$. elaphus). Reports that $E$. panticola from $C$. e. sibiricus from Kazakhstan did not differ in morphology from E. cervi from Polish red deer.

224. DEMIASZKIEWICZ, A.W. 1987. (Epizootiology of Elaphostrongylus infection of red deer in the Bialowieza forest). Medycyna Weterynaryjna 43: 208-211.

Numbers of first-stage larvae of the genus Elaphostrongylus peaked in February and May in two wild naturally infected red deer. Prevalence of larvae was highest in the snails Succinea putris (27\%) and Perforatella bidentata $(17 \%)$. Snails were infected from June to August with infections declining in September.

225. DROBISHCHENKO, N.I., and E.I. PRYADKO. 1969. (Predaceous fungi in the control of larvae of animal nematodes). In: Esenov. Sh.E. (Ed.), (Work on helminthology in Kazakhstan). Alma-Ata: Izdatel'stvo "Nauka" Kazakhstoi SSR, pp. 129-134.

Describe results of experimental studies designed to determine the efficacy of nematophagous predaceous fungi for catching first-stage larvae of E. panticola. Suggest spraying fungi conidia from aircraft in large scale operation.

226. DYKOVA, I. 1969. (Elaphostrongylus cervi Cameron, 1931 in the central nervous system of red deer (Cervus elaphus)). Folia Parasitologica (Prague) 16: 74

Subcutaneous tissues of red deer were commonly infected with $E$. cervi; cerebral and central nervous system involvement was also recorded.

227. ENGLISH, A.W., C.F. WATT, and W. CORRIGALL. 1985. Larvae of Elaphostrongylus cervi in the deer of Scotland. Veterinary Record 116: 254-256.

Examined feces of red deer, roe deer and reindeer. Found larvae in all three that were outside the range for Bicaulus sagittatus but within those of $E$. cervi.

228. ERIKSEN, L, J. MONRAD, and M. STEEN. 1989.

(Account of the thoracic connective tissue worm Elaphostrongylus cervi from feral red deer in Denmark). Dansk Veterinaertidsskrift 72: 732-736.

General review of parasite's life cycle, diagnosis, pathology, and prevalence in various regions of Denmark.
229. ERIKSEN, L., J. MONRAD, and M. STEEN. 1989. Elaphostrongylus cervi in Danish wild red deer (Cervus elaphus). Veterinary Record 124: 124.

One to 10 adult $E$. cervi were found in connective tissues and on the fascia between the thoracic and abdominal muscles of 10 of 12 farmed and feral red deer from Jutland and New Zealand. Two $E$. cervi were found in the longitudinal fissure of the brain of one animal.

230. GAUDERNACK, G., O. HALVORSEN, A. SKORPING and K.A. STOKKAN. 1984. Humoral immunity and output of first-stage larvae of Elaphostrongylus rangiferi (Nematoda, Metastrongyloidea) by infected reindeer, Rangifer tarandus tarandus. Journal of Helminthology 58: 13-18.

An indirect immunofluorescent technique demonstrated that sera from two reindeer in Norway infected with $E$. cervi contained antibodies against antigens on the cuticle of first-stage larvae. Show an inverse in output of first-stage larvae in the feces and decrease in specific antibody titre when animals are stressed and immunity drops. For males this is during the rutting season in autumn; for females it is at the end of winter before calving.

231. GROHOLT, L. 1969. (Elaphostrongylus rangiferi and its significance in practical reindeer meat inspection). Medlemsbl. Norsk Vet. Foren. 21: 382-388.

Elaphostrongylus rangiferi found at meat inspection in 52 of 4,736 reindeer carcasses. Parts of three heavily infected reindeer carcasses had to be trimmed and a fourth was condemned at inspection.

232. HALE, I. 1980. (Development of Elaphostrongylus cervi Cameron, 1931 in intermediate host). (Abstract of Dissertation). Wiener Tierärztliche Monatsschrift 67:378.

233. HALVORSEN, O. 1978. The presence of brainworm in a reindeer flock in relation to the quality of pasture, climate and management. Reindriftsnytt 1: 3-8.

234. HALVORSEN, O. 1978. Studies on the epidemiology of Elaphostrongylus rangiferi (Nematoda, Metastrongyloidea), a parasite of reindeer. 4th International Congress of Parasitology, Section C: 176-177.

235. HALVORSEN, O. 1979. The occurrence of Elaphostrongylus rangiferi (Nematoda,

Metastrongyloidea) in domestic reindeer in relation to climatic and topographic differences among summer pasture areas. Information, Institute of Parasitology, Abo Akademi, Finland 15: 23-24.

236. HALVORSEN, O. 1981. (Meningeal worm in reindeer in the Karasjok region). Reindriftsnytt 3: 14-15.

Refers to Elaphostrongylus.

237. HALVORSEN, O. 1983. The influence of climate on epidemiological dynamics. Nordic Council Arctic Medicine and Research Report Number 35: 69-71. 
The first-stage larvae of Elaphostrongylus rangiferi was cold-tolerant, but development in snails from the first to third-stage was temperature sensitive (i.e., faster development at warmer temperature), suggesting that warm summers may cause epizootics of disease in reindeer.

238. HALVORSEN, O. 1986. On the relationship between social status of host and risk of parasitic infection. Oikos 47: 71-74.

Found a positive relationship between high status of host and risk of infection (i.e., the heaviest calves - those of dominant mothers were those that were infected). Thus, larger calves risk ingesting more gastropods with larvae of $E$. rangiferi than smaller calves because they with their large mothers are dominant and presumably, eat more of the calcium-demanding forbs that reindeer select for and where more gastropods are found. This relationship may lower the overall pathogenicity of the parasite, increase suppression of host population growth, counteract inbreeding with the dominant animals, and stabilize selection.

239. HALVORSEN, O. 1986. Epidemiology of reindeer parasites. Parasitology Today 2: 334-339.

Describes physiological adaptations and life cycle strategies of $E$. rangiferi and the influences of insect harassment on reindeer behavior and of social structure on $E$. rangiferi infection. Suggests that the most important effects of infections on reindeer is not parasite-induced mortality, but parasite-induced reduction in individual growth. Animals mature sexually when they reach a certain size; if growth is reduced, age at first reproduction increases, and this reduces the population growth rate.

240. HALVORSEN, O., and R.M. ANDERSON. 1982. On the population biology of Elaphostrongylus rangiferi (Nematoda) in reindeer, Rangifer tarandus tarandus. Molecular Biochemical Parasitology supplement, p. 469.

Based on age-dependent prevalence and intensity of infection in a reindeer herd, life-expectancy of the adult worm was estimated at approximately 1 (in herd with large infection) to 3 years (herd with low levels of infection). Thus, parasite-induced mortality occurs in the herd with higher levels of infection.

241. HALVORSEN, O., and A. SKORPING. 1982. The influence of temperature on growth and development of the nematode Elaphostrongylus rangiferi Mitskevich in the gastropods Arianta arbustorum (L.) and Euconulus fulvus (Müller). Oikos 38: 285-290.

Development to the infective third-stage larva in A. arbustorum held at $12^{\circ} \mathrm{C}$ took from 11 days at $28^{\circ} \mathrm{C}$ to 75 days, and in $E$. fulvus held at $12^{\circ} \mathrm{C}$ took from 11.5 days at $24^{\circ} \mathrm{C}$ to 48.5 days. There was no development at $8^{\circ} \mathrm{C}$. Authors suggest that larvae that infect intermediate hosts one summer do not develop to the infective stage until the next summer.

242. HALVORSEN, O., and K. WISSLER. 1983. Methods for estimating the density of Elaphostrongylus rangiferi Mitskevich (Nematoda, Metastrongyloidea) larvae in faeces from reindeer, Rangifer tarandus L. Rangifer 3: 33-39.
An inverted microscope with plankton counting chambers is used to estimate density of $E$. rangiferi larvae in frozen reindeer feces. An average of 30 per cent more larvae were detected using the technique when compared to the Baermann Technique.

243. HALVORSEN, O., and K. WISSLER. 1983. Elaphostrongylus sp. (Nematoda, protostrongylidae) and other helminths in faeces of moose (Alces alces (L.)) in north Norway. Fauna Norvegica Series A, 4: 37-40.

Record prevalence of larvae of Elaphostrongylus sp. in feces of moose from two counties in Norway. State that fewer larvae occur in feces of moose than in feces of reindeer from the same area.

244. HALVORSEN, O., J. ANDERSEN, I. HJERMUNDRUD, and K. WISSLER. 1976. Studies on the epidemiology of Elaphostrongylus rangiferi (Nematoda, Metastrongyloidea), a parasite of reindeer. The occurrence and distribution of gastropods in a selected summer pasture. Norwegian Journal of Zoology 24: 461.

245. HALVORSEN, O., J. ANDERSEN, A. SKORPING, and G. LORENTZEN. 1980. Infection in reindeer with the nematode Elaphostrongylus rangiferi Mitskevich in relation to climate and distribution of intermediate hosts. In : Reimers, E., and S. Skjenneberg (eds.), Proceedings of the 2nd International Reindeer/Caribou Symposium, pp. 449-455.

Free-living first-stage larvae were cold-tolerant, and development of larvae in the gastropod intermediate host was temperature-dependent. Most infection occurred on a calcium-rich bog above timber line in late summer - early autumn.

246. HALVORSEN, O., A. SKORPING, and K. HANSEN. 1985. Seasonal cycles in the output of first stage larvae of the nematode Elaphostrongylus rangiferi from reindeer, Rangifer tarandus tarandus. Polar Biology 5: 49-54.

Found a host-sex related seasonal output of larvae in feces of free-ranging and captive reindeer. Recorded seasonal lows for male and female deer in summer, followed by annual high in autumn/early winter for males and late winter/spring for females. Adult worms live several years, thus, the cycle is linked to degree of host stress and the seasonally varying capacity of the host to react immunologically to the infection.

247. HALVORSEN, O., A. SKORPING, and K. BYE. 1989. Experimental infection of reindeer with Elaphostrongylus (Nematoda; Protostrongylidae) originating from reindeer, red deer, and moose. Canadian Journal of Zoology 67: 1200-1202.

Infective larvae experimentally grown in snails from first-stage larvae from Rangifer $t$. tarandus, Cervus elaphus atlanticus, and Alces alces were exposed to reindeer calves. None of five and none of three reindeer calves infected with larvae from red deer and moose, respectively, became infected, but 12 of 14 reindeer inoculated with reindeer-source larvae became infected. Suggest that several species of Elaphostrongylus parasitize palearctic cervids. Suggest that names $E$. cervi and $E$. rangiferi should be reserved for worms from red deer and reindeer, respectively. 
248. HELLE, O. 1980. (Elaphostrongylus cervi in red deer (Cervus elaphus) in Norway). Norsk Veterinaertidsskrift 92: 677-678.

Elaphostrongylus cervi was recovered from connective tissues of the muscles of deer collected from Tysnes in Sunnhordland, Norway.

249. HOLLANDS, R.D. 1985. Elaphostrongylus cervi cervi in the central nervous system of red deer (Cervus elaphus) in Scotland. Veterinary Record 116: 584-585.

250. HOLMSTROM, S., P. KORHONEN, S. NIKANDER, and T. RAHKO. 1989. (On the occurrence of lungworm infection in the reindeer in Finnish Eastern Lapland). Suomen Elainlaakarilehti 95: 178-181.

One of 91 Rangifer tarandus showed neurologic abnormalities attributed to infection with $E$. rangiferi. Worms were recovered from that animal and two others.

251. HOLT, G. 1982. (Demonstration of elaphostrongylosis in moose in South Norway gives reason for some anxiety).

Jakt-Fiske, og Friluftsliv 111: 33-34, 66. (cited in

Halvorsen and Wissler, 1983)

252. ISADOV, S.I., and K.S. OLESOVA. 1977.

(Elaphostrongyliasis in reindeer). Veterinaraya, Moscow,

No. 3: 74.

17 per cent of 1295 reindeer had evidence of Elaphostrongylus larvae in the lungs.

253. JORGENSEN, R.J., and F. VIGH-LARSEN. 1986. Preliminary observations on lungworms in farmed and feral red deer (Cervus elaphus) in Denmark. Nordisk Veterinaermedicin 38: 173-179.

Report Elaphostrongylus cervi (?) larvae in all farmed adult deer, but few feral deer.

254. KONTRIMAVICHUS, V.L., S.L. DELYAMURE, and S.N. BOEV. 1985. Principles of Nematodology, Ryzhikov, K.M. (ed.), Vol 26, Metastrongyloidea of domestic and wild animals. Osnovy Nematodologii, Izdatel'stvo "Nauka", 228 pp. Translation of 1976 Russian text by US Department of Agriculture and the National Science Foundation, Washington, D.C. 298 pp.

Differences in host species and geographic distribution were only criteria that supported subspecies designation of E. cervi. Thus, designations are $E$. cervi in Cervus elaphus in Europe; $E . c$. panticola in C. elaphus siberica and Cervus nippon in Asia; and E. c. rangiferi in Rangifer tarandus tarandus in Europe.

255. KOTRLA, R., and A. KOTRLY. 1977. Helminths of wild ruminants introduced into Czechoslovakia. Folia Parasitologica (Praha) 24: 35-40.

Report E. cervi (one of 25 parasite species) from white-tailed deer introduced into Czechoslovakia (52 deer examined). Estimated total population of white-tailed deer in 1977 was 200. Assume that deer acquired parasite from enzootic red deer.
256. KUMMENEJE, K. 1973. (Disease in reindeer caused by "brainworm"). Reindriftsnytt 1: 6.

257. KUMMENEJE, K. 1974. (Encephalomyelitis and neuritis in acute cerebrospinal nematodiosis in reindeer calves). Nordisk Veterinaermedicin 26: 456-458.

Infection with $E$. rangiferi caused acute inflammation in the cerebral white and grey matter, the spinal cord, the leptomeninges and the perineurium of spinal nerves, and neuritis of spinal nerves. Clinical signs were: general weakness, poor coordination of the hind legs, posterior paralysis, restlessness, vertigo, dyspnoea, and coughing.

258. KUTZER, E. 1987. (The application of the anthelmintic Ivomec (ivermectin) in game animals).

Verhandlungsbericht des XXI. Internationalen Symposiums des Osterreichischen Wildgehegeverbandes am 19 und 20 Juni, 1987, Bad Mitterndorf (Steiermark), Austria. Vienna, Austria; Veterinarmedizinsche Universitat (1987). 7-17.

Drug was ineffective against Elaphostrongylus cervi, even at higher doses, when give to game animals by adding and oral application in water to artificially-supplied food rations.

259. KUTZER, E., and H. PROSL. 1975. (Contribution to the knowledge of Elaphostrongylus cervi Cameron, 1931. 1: Morphology and diagnosis). Wiener Tierärztliche Monatschrift 62: 258-266.

Report E. cervi from red (Cervus elaphus hippelaphus) and roe deer (Capreolus capreolus capreolus) in Austria. Feel that both E. panticola and $E$. rangiferi are synonymous with E. cervi.

260. KUTZER, E., and H. PROSL. 1976. (Knowledge of Elaphostrongylus cervi Cameron, 1931. II. Biology). Verhandlungsbericht des XVIII. Internationalen Symposiums uber die Erkrankungen der Zootiere, 16-20 June, 1976, Innsbruck, Germany; Akademie-Verlag, Berlin. 239-243.

Review life cycle of $E$. cervi. Larvae develop in snails to the infective 3 rd-stage in 30 to 47 days and can live there for 2 years. When snails are eaten by red deer, larvae pass from the stomach to the intermuscular connective tissue of the shoulder, breast, and back. There, they mature. Eggs are laid in the small vessels and carried to the lungs where they develop into first-stage larvae. Larvae bore into the alveoli and migrate up the bronchial tree to the mouth, then are swallowed and eventually passed with the feces.

261. LANKESTER, M.W. 1976. A protostrongylid nematode of woodland caribou and implications in moose management. Proceedings of the North American Moose Conference and Workshop. 12: 173-190.

Reports 1st-stage larvae indistinguishable from those fo $E$. cervi in 80 per cent of woodland caribou feces in central Newfoundland, Canada.

262. LANKESTER, M.W. 1977. Neurologic disease in moose caused by Elaphostrongylus cervi Cameron 1931 from 
caribou. Proceedings of the North American Moose Conference and Workshop 13: 177-190.

Report on the experimental infection of a one-month-old woodland caribou and a one-month-old moose with $E$. cervi (source larvae from caribou of Newfoundland, Canada). The prepatent periods were 74 and 64 days postexposure, respectively. Postulates that worms develop in meningeal spaces and then migrate along the spinal cord and out to fascia via peripheral nerves.

263. LANKESTER, M.W., and T.H. NORTHCOTT. 1979. Elaphostrongylus cervi Cameron 1931 (Nematoda: Metastrongyloidea) in caribou (Rangifer tarandus) of Newfoundland. Canadian Journal of Zoology 57: 1384-1392.

Decribe $E$. cervi from woodland caribou of Newfoundland. Up to 88 per cent animals infected. Pathologic lesions are described in addition, larvae identical to those of $E$. cervi occurred in feces of barren ground caribou ( $R$. $t$. groenlandicus) of the Kaminuriak herd and of woodland caribou in northern Labrador.

264. LANKESTER, M.W., V.J. CRICHTON, and H.R. TIMMERMANN. 1976. A protostrongylid nematode (Strongylida: Protostrongylidae) in woodland caribou (Rangifer tarandus caribou). Canadian Journal of Zoology 54: 680-684.

Report 1st stage larvae indistinguishable from those of $E$. cervi in 5 to 20 per cent of woodland caribou in central Canada.

14. LANKESTER, M.W., and D. FONG. 1989. Distribution of elaphostrongyline nematodes (Metastromgyloidea: Protostrongylidae) in cervidae and possible effects of moving Rangifer spp. into and within North America. Alces 25: 133-145.

Review known host and geographic distributions of meningeal worm, Parelaphostrongylus tenuis, two muscleworms, $P$. andersoni and $P$. odocoilei, and tissue worm, Elaphostrongylus cervi, the latter known in North America only from caribou in central Newfoundland where Lankester feels it was introduced with reindeer brought from Norway. Authors suggest that there have been opportunities for $E$. cervi to spread to mainland Canada via translocations of reindeer and caribou.

265. LORENTZEN, G., and O. HALVORSEN. 1986. Survival of the first stage larva of the metastrongyloid nematode Elaphostrongylus rangiferi under various conditions of temperature and humidity. Holarctic Ecology 9: 301-304.

Survival of la vae from feces and kept in water decrease from 210 days at $6^{\circ} \mathrm{C}$ to $<80$ minutes at $50^{\circ} \mathrm{C}$. Freezing larvae to $-80^{\circ} \mathrm{C}$ for one year did not affect survival. Repeated freezing and thawing reduced survival to $<77$ days. At relative humidities of 20 and 22 per cent, all larvae died within 11 days.

266. LUBIMOV, M.P. 1945. (New worm diseases of the brain of deer with velvet antlers). Sbornik Nauchno-Issledovatel'skikh Rabot Laboratorii Pantovogo Olenovodstvo Ministerstvas Sovkhozow SSR, 1: 225-232.
Describes $E$. panticola as a common parasite of red deer, Cervus elaphus sibiricus, and sika deer, C. nippon, on game farms in Kazakhstan, USSR.

267. LUBIMOV, M.P. 1948. (New helminths in the brain of maral deer). Trudy Gel'mintologicheskoi Laboratorii Akademii Nauk SSSR 1: 198-201.

An abstract of his dissertation.

268. LUBIMOV, M.P. 1959. (Seasonal dynamics of elaphostrongylosis and setariasis in Cervus elaphus maral). Trudy Gel'mintologicheskoi Laboratorii Akademii Nauk SSSR 9: 155-156.

Suggests that the central nervous system is an abnormal site for adult E. panticola. Reports that worms are more common in the central nervous system in winter than in autumn. Also reports Setaria altaica from the brain and spinal cord.

269. LUBIMOV, M.P. 1959. (New observations on the epizootiology, prophylaxis, and therapy of elaphostrongylosis in maral deer). Sbornik Nauchnykh Rabot Nauchnye-Issledovatel'skoi Laboratorii Pantovogo Olenovodstvo, Gorno-Altai pp. 164-214.

270. MASON, P.C. 1975. Elaphostrongylus cervi (Protostrongylidae: Elaphostrongylinae) in New Zealand cervids. Proceedings of the 1975 Conference of the New Zealand Society for Parasitology.

271. MASON, P.C. 1979. Tissue worm in red deer. Biology and significance. AgLink FPP 249, Media Services, MAF, Wellington, New Zealand.

Name "tissue worm" coined for E. cervi.

272. MASON, P.C. 1989. Elaphostrongylus cervi - a review. Surveillance 16: 3-10.

Reviews many aspects of $E$. cervi. This parasite "has recently achieved prominence in New Zealand because of the requirement that it be absent from deer exported to Australia and some other countries".

273. MASON, P.C., and H.J.F. MCALLUM. 1976. Dictyocaulus viviparus and Elaphostrongylus cervi in wapiti. New Zealand Veterinary Journal 24: 23.

New Zealand report in American elk. Documents condemnation of a few infected carcasses.

274. MASON, P.C., and N.R. GLADDEN. 1983. Survey of internal parasitism and anthelmintics used in farmed deer. New Zealand Veterinary Journal 31: 217-220.

Found no spined larvae during examination of feces from 12 fallow deer farms, but did find $E$. cervi larvae in feces from 37 or 103 red deer farms. Counts were usually $<1$ larva per gram of feces.

275. MASON, P.C., N.R. KIDDEY, R.J. SUTHERLAND, D.M. RUTHERFORD, and A.G. GREEN. 1976. 
Elaphostrongylus cervi in red deer. New Zealand Veterinary Journal 24: 22-23.

First report of parasite in New Zealand. Documents condemnation of 22 of 91 infected carcasses in 1975.

276. MITSKEVICH, V.Y. 1957. (The causative agent of elaphostrongylosis of reindeer and its cycle of development). Tezisy Doklady Nauchnye Konferentsii Vsesoyuznogo Obsb. Gel'mintologov Posviash 40. g. Oktiabr. Sotsial. Revoliuts., Dec. 11-15. Chast 1: 206-207.

Reference in Index-Catalogue of Medical and Veterinary Zoology, Supplement 11, Authors: A to Z, United States Department of Agriculture, 1961, p.241. Reports on development of E. rangiferi larvae in variety of snails. Larvae develop to the infective stage in 27-35 days. The prepatent period is 3-4 months.

277. MITSKEVICH, V.Y. 1958. (On the interpretation of the developmental cycle of the nematode Elaphostrongylus rangiferi $\mathrm{n}$. $\mathrm{sp}$. from a reindeer). Doklady Akademii Nauk SSSR 119: 621-624.

Describes E. rangiferi from the central nervous system and skeletal musculature of Rangifer tarandus tarandus in northern USSR.

278. MITSKEVICH, V.Y. 1960. (Elaphostrongylus rangiferi n.sp. in deer). Trudy Instituts Zoologicheskogo, Akademii Nauk SSSR Alma-Ata 12: 115-119.

Describes $E$. rangiferi from Rangifer tarandus tarandus.

279. MITSKEVICH, V.Y. 1963. (Elaphostrongylosis in reindeer). In: (Helminths of man, animals and plants and their control). Papers on helminthology presented to Academician K.I. Skryabin on his 85th birthday. Izdatel'stvo Akademii Nauk SSSR, Moscow, pp. 421-423.

280. MITSKEVICH, V.Y. 1963. (Elaphostrongylus infection in reindeer). Materiali Nauchnye Konferentsii (XII) Leningradski Veterinarni Instituts, May 20-26: 102-105.

281. MITSKEVICH, V.Y. 1964. (Life history of Elaphostrongylus rangiferi Miz., 1958). In: Boev, S.N. (ed.) (Parasites of farm animals in Kazakhstan). Izdatel'stvo Akademii Nauk SSR Alma-Ata, 3, 49-60.

Records neurologic disease and death in two domestic lambs and one guinea pig infected experimentally with $E$. rangiferi within 2 weeks of exposure to third-stage larvae. First-stage larvae survived 11 months in water, but much less time following a number of repeated drying and moistening. Similar results followed freezing, and freezing and thawing. Larvae survived up to 2 years in feces on open pasture.

282. MUNRO, R. 1988. Pulmonary parasites: pathology and control. In Reid, H.W. (ed.) The management and health of farmed deer, A Seminar in the CEC Programme of Coordination of Research in Animal Husbandry,
Edinburgh, UK, 10 - 11 December, 1987. Dordrecht, Netherlands, Kluwer Academic Publishers.

Briefly reviews the intermediate host range, prevalence, histopathology and control of Elaphostrongylus cervi.

283. MUNRO, R. and A.R. HUNTER. 1983. Histopathological findings in the lungs of Scottish red deer and roe deer. Veterinary Record 112: 194-197.

284. NILSSON, O. 1971. The inter-relationship of endoparasites in wild cervide (Capreolus capreolus L. and Alces alces L.) and domestic ruminants in Sweden. Acta Veterinaria Scandinavica 12: 36-68.

Reports Elaphostrongylus cervi from roe deer (new host record) and moose in Sweden.

285. NORDKVIST, M. 1971. The problems of veterinary medicine in reindeer breeding. Veterinary Medical Review Numbers 2/3: 405-413.

Mentions Elaphostrongylus rangiferi.

286. NORDKVIST, M., O. RONEUS, and O. NILSSON. 1963. (Continued investigations on cerebrospinal nematodiasis in reindeer caused by Elaphostrongylus rangiferi). Proceedings of the 9th Nordic Veterinary Congress, Copenhagen, July 4-7, 1962, 1: 221.

287. NORDKVIST, M., C. REHBINDER, D. CHRISTENSSON, and C. RONNBACK. 1983. A comparative study of the efficacy of four anthelmintics on some important reindeer parasites. Rangifer 3: 1938.

288. NORDKVIST, M., D. CHRISTENSSON, and C. REHBINDER. 1984. A deworming field trial with ivermectin in reindeer. Rangifer 4: 10-15.

Reindeer in Sweden were treated with ivermectin at $0.2 \mathrm{mg} / \mathrm{kg}$, then returned to pasture for 150 days during winter. Efficacy against Elaphostrongylus rangiferi was 100 per cent based on necropsy of five treated and five control reindeer.

289. OSIPOV, P.P. 1964. (Effect of feeding phenothiazine to Cervus elaphus on the fecal counts of Elaphostrongylus, Dictyocaulus, and Bicaulus larvae). In Boev, S.N.(Ed.) (Parasites of farm animals in Kazakhstan). Izdatel'stvo Akademii Nauk Kazakhskoi SSR, Alma-Ata, No. 3, 98-100.

290. OTTESTAD, A.K. 1983. (The occurrence of Elaphostrongylus cervi in a population of red deer (Cervus elaphus)). Candidatus realium thesis, University of Troms $\emptyset$, Troms $\emptyset$, Norway.

291. PANIN, V.Y.. 1964. (Developmental cycle of Elaphostrongylus panticola Lubimov, 1945). In: Boev, S.N.(ed.) (Parasites of farm animals in Kazakhstan). Izdatel'stvo Akademii Nauk Kazakhskoi SSR, Alma-Ata, No. 3: 34-48. 
Translated into english by the Israel Program for Scientific Translations, Jerusalem. Available from U. S. Dept. of Commerce, Clearinghouse for Federal Scientific and Technical Information, Springfield, VA 22151. Reports the prepatent period of E. panticola as being 4 months post-exposure. Found natural infections in 15 species of terrestrial snails and for as long as 2 years after exposure to first-stage larvae. Attempts to experimentally infect domestic sheep failed.

292. PANIN, V.Y. 1964. (Role of terrestrial molluscs in spreading Elaphostrongylus in deer.) In: Boev, S.N.(ed.) (Parasites of farm animals in Kazakhstan). Izdatel'stvo Akademii Nauk Kazakhskoi SSR, Alma-Ata, No. 3: 79-83.

Reports on the prevalence of larvae in 11 genera (15 species) of snails.

293. PANIN, V.Y. 1965. (Epizootiology and prophylaxis of elaphostrongylosis of Siberian maral.) Izdatel'stvo Akademii Nauk SSR, Alma-Ata, Ser. B, Vol. 2: 56-63.

294. PANIN, V.Y., and D.I. RUSIKOVA. 1964. (Susceptibility of molluscs to infection with larvae of Elaphostrongylus panticola Lubimow, 1945). In: Boev, S.N.(ed.) (Parasites of farm animals in Kazakhstan). Izdatel'stvo Akademii Nauk Kazakhskoi SSR, Alma-Ata, No. 3: 84-89.

18 of 29 species of molluscs were successfully infected with $E$. cervi.

295. PETERS, S.S., and J.M. KING. 1959. Newfoundland caribou disease investigation, 1958. Department of Mines and Resources, Wildlife Division Progress Report. 55 pp.

Found three worms identified as Elaphostrongylus sp. under the skin of caribou from Newfoundland.

296. POLYANSKAYA, M.V. 1963. (On elaphostrongylosis in reindeer). In: (Helminths of man, animals, and plants and their control). Papers presented to Academician K. I. Skrjabin on his 85th birthday. Izdatel'stvo Akademii Nauk SSR, Moscow, pp. 424-425.

English translation available from the U. S. Department of Commerce, Clearinghouse for Federal Scientific and Technical Information, Springfield, VA, USA.

297. POLYANSKAYA, M.V. 1964. (Study of the etiology of the so-called cerebral disease of reindeer elaphostrongylosis .) Materialy Nauchnye Konferentsii Vsesoyuznogo Obchtchesztva Gel'mintologov Moscow, part 2, pp. 73-76.

298. POLYANSKAYA, M.V. 1965. (On the forms of elaphostrongylosis of reindeer.) Materialy Nauchnye Konferentsii Vsesoyuznogo Obchtchesztva Gel'mintologov Moscow, part 2, pp. 205-207.

299. POLYANSKAYA, M.V. 1965. (A study of the paraparesis of the pelvic limbs of reindeer). Scientific Records of O.V. Kuusinen State University (Petrozavodsk) 13: 19-23.
300. PRESIDENTE, P.J.A. 1984. Parasites of farmed and free-ranging deer in Australia. Pp 623-643 In: "Deer Refresher Course." Post-Graduate Comittee in Veterinary Science, Proceedings Number 72, 10-14 December, 1984, University of Sydney, Sydney, New South Wales 2570, Australia.

Reviews the biology of $E$. cervi and warns of significance of its presence and spread in red deer of New Zealand and potential introduction into Australia. Three slugs (Arion hortensis, Deroceras reticulatum, and Lehmannia flava) and one snail (Helix aspersa) are common in Australia and have been identified as potential intermediate hosts of E. cervi. In February, 1984, Australia approved the importation of deer from New Zealand.

301. PRESIDENTE, P.J.A. 1986. First report of the tissue worm in Australia. The Federal Deerbreeder 5(3): 13-17.

See next reference.

302. PRESIDENTE, P.J.A. 1986. Tissue worm: Implications for live deer exports. In: Owen, P. (Ed.) Deer farming into the nineties. Based on the proceedings of the Australian Deer 86 conference. Owen Art and Publishing, Brisbane. pp. 192-202.

Reports on the finding of Elaphostrongylus cervi larvae in the feces of a wapiti cow imported from New Zealand into Australia and the resulting cessation of live deer importation.

303. PRESIDENTE, P.J.A. A standardized procedure to test imported deer for larvae of Elaphostrongylus cervi.

Unpublished report for the Commonwealth Department of Primary Industries and Energy, Animal Quarantine and Inspection Service, $4 \mathrm{pp}$.

Unpublished report available from Dr. Presidente, Veterinary Research Institute, Attwood and Parkville, Department of Agriculture and Rural Affairs, 475 - 485 Mickleham Road, Attwood, Victoria 3049, Australia.

304. PROSL, H., and E. KUTZER. 1974. (Elaphyostrongylus infection in red deer (Cervus elaphus)). (Abstract). In: 3rd International Congress of Parasitology. Proceedings, Volume 2 Vienna, Austria; FACTA Publication. 721.

305. PROSL, H., and E. KUTZER. 1980. Zur biologie und bekampfung von Elaphostrongylus cervi. Zeitschrift fur Jagdwissenschaft 26: 198-207.

Parasite common in Cervus elaphus hippelaphus. Adult worms located in the fascia and intermuscular tissues of the neck, breast, and shoulder muscles, but they are also occur between the membranes of the brain and spinal cord. Peak shedding of larvae occurred in February and March; few larvae were shed between May and October. Infection was controlled with fenbendazole given in food at $3 \times 7.5 \mathrm{mg}$ or $5 \times 3 \mathrm{mg} / \mathrm{kg}$ body weight.

306. PROSL, H., and E. KUTZER. 1980. Zur pathologie des Elaphostrongylus befalles beim Rothirsch (Cervus elaphus hippelaphus). Monatshefte fur Veterinaermedizin 35: 151-153. 
Postulate that eggs can be carried to the lungs by the blood. E. cervi is one of the most common endoparasites of red deer in central Europe, but causes few problems to the host. Therefore, they postulate that the European red deer (Cervus elaphus hippelaphus) is the original host of E. cervi.

307. PROSL, H, and E. KUTZER. 1982. Annual rhythm in the excretion by red deer (Cervus elaphus) of Dictyocaulus viviparus, Varestrongylus sagittatus and Elaphostrongylus cervi larvae. Angewandte Parasitologie 23: 9-14.

Twenty to 30 fecal samples from 150 deer were examined 1 to 3 times a month for 4 years for larvae. Maximum numbers of larvae were found in April to June (D.v), February to April (E.c.), December to April (V.s.). Treatment with fenbendazole produced the best results when administered in November-December.

308. PRYADKO, E.I. 1967. (Elaphostrongylus, a brain infection of deer). Vestnik Sel'skokhozyaistvenno Nauk, Alma-Ata, Vol. 1, pp. 105-108.

Reports E. panticola from sika deer, C. nippon.

309. PRYADKO, E.I. 1967. (Hyphomycetes predatory on helminths.) Parazitologiya 1: 257-262.

Confirms efficacy of predatory fungi against $E$. panticola larvae in a field experiment. Concludes that one should disseminate fungi on pasture rather that feeding it to the host, red deer.

310. PRYADKO, E.I. 1972. (Systematic status of Capreolus in the light of helminthological data). Zoologicheskij

Zhurnal 51: 1092-1093.

Roe deer do not become infected with elaphostrongylines confirming that Capreolus is of more ancient origin than other deer genera and represents an isolated systematic group.

311. PRYADKO, E.I. 1976. (Helminths of Deer). Izadatel'stvo Akademii Nauka Kazahkskoi SSR. 229 pp.

Lists Alces alces as host of Elaphostrongylus cervi in USSR. Calls E. cervi the most pathogenic nematode on deer breeding farms in eastern Kazakh SSR. In the central nervous system of maral deer and muscles of $C$. nippon. Feels that $E$. panticola and $E$. rangiferi are synonymous with $E$. cervi.

312. PRYADKO, E.I. 1976. (The susceptibility of marals to reinfection with Elaphostrongylus cervi panticola). Third International Symposium of the Helminthological Institute, Kosice, Czechoslovakia. 2 pp.

Experimental infection in Cervus elaphus sibiricus.

313. PRYADKO, E.I., and V.I. TETERIN. 1964. (Experimental treatment of elaphostrongylosis in Cervus elaphus). In: Boev, S.N.(ed.) (Parasites of farm animals in Kazakhstan). Izadatel'stvo Akademii Nauk Kazakhskoi SSR, Alma-Ata, No. 3: 90-97.

314. PRYADKO, E.I., and N.I. DROBISHCHENKO. 1967. (Predacious fungi (Hyphomycetes) and their possible use in the control of elaphostrongylosis). Helmintholologia, Yr. 1966, 7: 139-149.

Cultivated the predaceous fungus Arthrobotrys oligospora in deer feces infected with larvae of Elaphostrongylus panticola. The fungi reduced the number of larvae considerably, but spores did not survive passage through the deer's gut.

315. PRYADKO, E.I., and S.N. BOEV. 1971. (Systematics, phylogeny and evolution of Elaphostrongylinae nematodes of deer). Izdatel'stvo Akademii Nauk Kazakhskoi SSR, Seriya Biologicheskaya. No. 5, 41-48.

Found considerable overlap in morphological characters within the genus Elaphostrongylus. Propose one genus with following subspecies: E. c. cervi from Cervus elaphus elaphus; E. c. panticola from $E$. elaphus sibiricus and $C$. nippon; and $E$. c. rangiferi from Rangifer tarandus. Moved Odocoileostrongylus odocoilei and $O$. tenuis to genus Parelaphostrongylus.

316. PRYADKO, E.I., S.N. VISOKOV, and V.S. FROLOV. 1962. (Elaphostrongylosis of deer in eastern Kazakh SSR.). Tezisy Dokladov Nauchno-Proizvodstrennoi Konferentsii po Gel'mintologii v Dzhambule: 57-58.

Deer up to 18 months of age were most susceptible to infection; clinical signs were most apparent in winter.

317. PRYADKO, E.I., S.N. VISOKOV, and V.S. FROLOV. 1963. (Helminths of ungulates of Kazakhstan.

Epizootiology of Elaphostrongylus in maral deer). In: Boev, S.N.(Ed.) (Parasites of farm animals in Kazakhstan). Izdatel'stvo Akademii Nauk Kazakhskoi SSR, Alma-Ata, No. 3: 74-85.

Report that 60-82 per cent of maral deer, C. elaphus, and 52 per cent of sika deer, $C$. nippon in the Altai region of the USSR were passing larvae of E. cervi. Percent prevalences in calves, yearlings and older animals were $4.5,95-100$, and $71-86$ (red deer) and 10,60, and 62 (sika deer). Numbers of larvae increased in feces in winter suggesting that animals become infected in late summer and autumn. Clinical signs of disease included: weakness, paresis, loss of coordination in hind quarters, circling, erratic head movements, aggressiveness, lethargy, isolation from the herd, and ultimately complete paralysis.

318. PRYADKO, E.I., V.A. SHOL, T.K. BEISOVA, and V.I. TETERIN. 1964. (Helminths of Cervus elaphus sibiricus and $C$. nippon and their incidence in deer farms in the Altay region of the Kazakh SSR.). In: Boev, S.N.(ed.) (Parasites of farm animals in Kazakhstan). Izdatel'stvo Akademii Nauk Kazakhskoi SSR, Alma-Ata, No. 3: 61-70.

Reports E. panticola.

319. PRYADKO, E.I., N.I. DROBISHCHENKO, V.I. TETERIN, and V.A. SHOL. 1968. (Efficacy of thiabendazole against Elaphostrongylus infection of marals). Materialy Konferentsii Posvyashchennoi Pamyati N.V. Badanina, Tashkent, pp. 248-249. 
320. PRYADKO, E.I., V.A. SHOL, V.I. TETERIN, and N.I. DROBISHCHENKO. 1971. (Screening for therapeutic compounds to control Elaphostrongylus infection of maral deer). Sbornik Rabot po Gel'mintologicheskoi 90 letiyu so dnya rozhderiya Akademika K.I. Skryabin. Moscow: Izdatel'stvo ‘Kolos', pp 313-316.

Thiabendazole at $30-100 \mathrm{mg} / \mathrm{kg}$ body weight was at least 99 per cent effective against larvae and adults.

321. REHBINDER, C., D. CHRISTENSSON, and I. FORSSELL. 1979. (Investigations on parasitic visceral granulomas in reindeer). Nordisk Veterinaermedicin 31: 282-283.

Parasitic granulomas in the viscera were digested for larvae of $E$. rangiferi. Larvae of $E$. rangiferi were found in the lungs as were smaller larvae, probably another member of the protostrongylidae.

322. REHBINDER, C., I. FORSSELL, M. NORDKVIST, and P. VON SZOKOLAY. 1982. Efficacy of mebendazole on Elaphostrongylus rangiferi in reindeer. In: Fowler, M.E.(ed.). Wildlife diseases of the Pacific Basin and other countries. Proceedings of the Fourth International Congress of the Wildlife Disease Association, Sydney, Australia. 25-28 August 1981: 208-212.

Brief summarization of a later article by Rehbinder et al. (reference not available) in Nordisk Veternaermedicin 33: 150-158. 1981. Mebendazole at $6 \mathrm{mg} / \mathrm{kg}$ body weight was given in feed daily for 10 days and by day 43 no more larvae were recovered.

323. RONEUS, O., and M. NORDKVIST. 1962. Cerebrospinal and muscular nematodiasis (Elaphostrongylus rangiferi) in Swedish reindeer. Acta Veterinaria Scandinavica 3: 201-225.

Of 20 reindeer necropsied, eight of which had shown clinical signs, E. rangiferi was recovered from the central nervous system of six and from the skeletal muscle of three of seven. Lesions are described. Clinical signs included weakness, paresis, ataxia of the hind limbs, cervical rigidity, head held to one side, and ears asymmetrical in position.

324. SCHWANGART, F. 1940. (Endemic paresis of red deer and tuberculosis in deer). Berliner Münchener

Tierarztliche Wochenschrift 6: 61-66.

325. SHOL, V.A., E.I. PRYADKO, V.I. TETERIN, and N.I. DROBISHCHENKO. 1969. (Thiabendazole against some helminthiases of marals (Cervus elaphus maral)). In: Esenov, Sh.E. (ed.), (Work on helminthology in Kazakhstan). Alma-Ata: Izdatel'stvo Nauk Kazakhstoi SSR, pp. 103-112.

Single dose of thiabendazole of $300-500 \mathrm{mg} / \mathrm{kg}$ body weight, or daily treatment for 7 days of $60 \mathrm{mg} / \mathrm{kg}$, was 100 per cent effective in maral.

326. SKORPING, A. 1982. Elaphostrongylus rangiferi: influence of temperature, substrate, and larval age on the infection rate in the intermediate snail host, Arianta arbustorum. Experimental Parasitology 54: 222-228.

Author shows a five-fold increase in infection rate with the temperature range of 4 to $28^{\circ} \mathrm{C}$. Higher infections occurred in snails exposed to larvae in water than on soil or lettuce.

327. SKORPING, A. 1984. Density dependent effects in a parasitic nematode, Elaphostrongylus rangiferi, in the snail intermediate host. Oecologia 64: 34-40.

Found an inverse relationship between infection level and rate of larvae development in Arianta arbustorum. Exposure of snails to 3.8 or 67 larvae per snail resulted in a development to the infective stage on day $28\left(28^{\circ} \mathrm{C}\right)$ of 87 and 2 per cent, respectively.

328. SKORPING, A. 1985. Lymnea stagnalis an experimental host for the protostrongylid nematode Elaphostrongylus rangiferi. Zeitschrift fur Parasitenkunde 71: 2654-270.

An aquatic snail!

329. SKORPING, A., and O. HALVORSEN. 1980. The susceptibility of terrestrial gastropods to experimental infection with Elaphostrongylus rangiferi (Mitskevich) (Nematoda: Metastrongyloidea). Zeitschrift fur Parasitenkunde 62: 7-14.

All of 16 species of terrestrial gastropods collected in northern Norway were susceptible to infection by $E$. rangiferi. The most suitable hosts appeared to be Discus ruderatus, Arion silvaticus Deroceras laeve, Euconulus fulvus and Trichia hispida.

330. SMIRNOV, YU.V. 1973. (The clinical signs and pathogenesis of Elaphostrongylus infection in Rangifer tarandus). Sbornik Nauchnykh Rabot Murmanskoi Olenovodnoi Opytnoi Stantsii. Issue 2, 53-58.

The clinical signs of Elaphostongylus infection in Rangifer tarandus in the Murmansk region, USSR, are described. A slight neutrophilic leukocytosis and eosinophilia (up to $17 \%$ ) were seen in chronic infections.

331. SMIRNOV, Yu.V. 1976. (Study of the efficacy of some anthelmintics in Elaphostrongylus infections in Rangifer tarandus). Sbornik Nauchnykh Rabot Murmanskoi Olenovodnoi Opytnoi Stantsii. Issue 3, 58-61.

Cyazide at $34 \mathrm{mg} / \mathrm{kg}$ body weight given 2 or 3 times at 1-day intervals reduced the number of Elaphostrongyluis larvae in feces.

332. STEEN, M. 1989. Elaphostrongylus infection in elks (Alces alces). Svensk Veterinartidning 41: 523-526.

Reviews life cycle, clinical signs, and histpathology and distribution of cases (1985 - 1987) of infection of moose with Elaphostrongylus in Sweden.

333. STEEN, M., and C. REHBINDER. 1986. (Nervous tissue lesions caused by elaphostrongylosis in wild Swedish moose). Acta Veterinaria Scandinavica 27: 326-342. 
Report losses of 35 moose, mostly calves, in northern Sweden. 17 (15 calves) of 35 moose were infected. Pathological findings are described.

334. STEEN, M., and L. ROEPSTORFF. 1990. Neurological disorder in two moose claves (Alces alces L.) naturally infected with Elaphostrongylus alces. Rangifer, Special Issue No. 3: 399-406.

335. STEEN, M., A.G. CHABAUD, and C. REHBINDER. 1989. Species of the genus Elaphostrongylus parasite of Swedish cervidae. A description of E. alces n. sp. Annals de Parasitologie Humaine et Comparee 64: 134-142.

Describes $E$. alces from moose. Differentiates it from E. rangiferi of reindeer and $E$. cervi of red deer. Moose specimens were found epidurally along the spinal cord while specimens from reindeer and red deer were from the muscle fascia.

336. STUVE, G. 1986. The prevalence of Elaphostrongylus cervi infection in moose (Alces alces) in southern Norway. Acta Veterinaria Scandinavica 27: 397-409.

Prevalence data based on first-stage larvae in feces, eggs, larvae and lesions in lungs. Found no relationship between prevalence and moose density. Highest prevalences in moose occurred where there were infected red deer. Suggests that moose show resistance to $E$. cervi because no larvae were found in the feces of old animals. Did not consider parasite to be particularly pathogenic for moose, although carcass weights of infected adults were much lower than that of uninfected adults.

337. STUVE, G. 1987. Elaphostrongylus cervi infection in moose (Alces alces). Prevalence and pathological changes in relation to age and season. Acta Veterinaria

Scandinavica 28: 157-164.

Prevalence was 85 and 57 per cent in calves shot in spring and autumn, respectively. There was no difference in carcass weights of infected and non-infected calves. Worms were only found in the epidural space of the central nervous system and no clinical signs were observed. The lungworm Varestrongylus alces was found in 26 per cent of 70 calves.

338. STUVE, G., and A. SKORPING. 1987. Experimental Elaphostongylus cervi infection in moose (Alces alces). Acta Veterinaria Scandinavica 28: 165-171.

Prepatent period of $E$. cervi in 8-wk-old calf given 360 infective larvae was 63 days. Calf was clinically and intermittently lame and stiff with mild ataxia for 3 months beginning 75 days after inoculation. Adult worms were found in the epidural space of the central nervous system and in skeletal muscles.

339. SUGAR, L. 1978. (Nematode infection of wild ruminants in Hungary. I) Parasitologia Hungarica 11: 146-148.

Found E. cervi in red, roe (3/12) and fallow deer (1/3) from Hungary. Setaria cervi, normally found in the abdominal cavity of red deer, was found in the central nervous system of six animals.

340. SUGAR, L., and A. KAVAI. 1977. (The occurrence of Elaphostongylus cervi Cameron, 1931 in a red deer population in Hungary). Parasitologia Hungarica 10: 95-96.

32 of 71 red deer (Cervus elaphus hippelaphus) from Hungary including 10 of 25 calves were found to be infected with E. cervi. From one to seven worms were recovered from the the skull and one to 40 from the muscles.

341. SUGAR, L., and P. SARKOZY. 1988. Lungworm control with albendazole (Vermitan $\circledast$ ) in captive red deer herds.

Verhandlungsbericht des 30. Internationalen Symposiums uber die Erkrankungen der Zoo- und Wildtiere Sofia 1988. Akadémie-Verlag Berlin (1988): 149-152.

Albendazole at various dose regimes (single and multiple oral administration via food and drench) and ivermectin at $0.3 \mathrm{mg} / \mathrm{kg}$ body weight injected once subcutaneously, controlled clinical outbreaks of mixed nematode infections including Elaphostrongylus cervi at a red deer farm based on fecal examinations made 1,3, and 6 weeks after treatment. At 6 weeks post-treatment with Albendazole, 15 of 26 deer were shedding larvae of E. cervi while 1 or 5 deer receiving ivermectin was shedding.

342. SUTHERLAND, R.J. 1976. Elaphostrongytus cervi in cervids in New Zealand 1. The gross and histological lesions in red deer (Cervus elaphus). New Zealand Veterinary Journal 24: 263-266.

Describes gross and histological lesions in connective tissue, lymph nodes and lungs of red deer.

343. SVARC, R., E.I. PRYADKO, Z. KH. TAZIEVA, and A. PAJERSKY. 1985. The larval stages of Elaphostrongylus cervi panticola Lubimov, 1945. Helminthologia 22: 171-180.

First, second and third stages of larval development in Succinea altaica lasted from 1 to 25,26 to 62 , and 63 to 70 days, respectively following exposure to first-stage larvae. Cellular changes are described.

344. TETERIN, V.I. 1969. (Some data on the diagnosis Dictyocaulus and Elaphostrongylus infections in deer). In: Esenov, Sh.E. (ed.), (Work on Helminthology in Kazakhstan). Alma-ata: Izdatel'stvo "Nauka" Kazakhskoi SSR, pp. 125-128.

Describes a modification of the Baermann Technic for detection of lungworm larvae in feces of red deer. Staining larvae helped.

345. VSEVOLODOV, B.P., and E.I. PRYADKO. 1964. (Materials on pathological morphology in cerebral elaphostrongylosis of marals). In: Boev, S.N. (ed.) (Parasites of farm animals in Kazakhstan). Izdatel'stvo Nauk Kazakhskoi SSR, Alma-Ata, No. 3: 70-77.

346. VSEVOLODOV, B.P., and G.O. KHALFIN. 1974. (Morphological study of toxicity of thiabendazole). Vestnik Sel'skokhozyaistvennoi Nauki Kazakhstana (Kazakstan Auyl Sharuashylyk Gylymynyn Habarshysy)(1974) Number. 10: 68-70. 
Necropsy of Cervus elaphus maral at 3,4, or 5 days after treatment with thiabendazole at $50 \mathrm{mg} / \mathrm{kg}$ body weight daily for 7 days was "fully effective against Elaphostrongylus cervi panticola.

347. WATSON, T.G. 1980. Elaphostrongylus cervi Cameron in Canada and New Zealand; an historical overview. Proceedings of the 8th Annual Meeting of the New Zealand Society for Parasitology, Palmerston North, 20-22 August, 1980. Abstract, New Zealand Journal of Zoology 7:604.

348. WATSON, T.G. 1981. Elaphostrongyulus cervi Cameron, 1931 and elaphostrongylosis: a review. Proceedings of a Deer Seminar for Veterinarians, Deer Advisory Panel, New Zealand Veterinary Association, Queenstown: pp 94-103.

Reviews literature and discusses importance of parasite to deer farming in New Zealand.

349. WATSON, T.G. 1983. Some clinical and parasitological features of Elaphostrongylus cervi infections in Cervus elaphus. New Zealand Journal of Zoology 10: 129

(Abstract only).

Gave 17 red deer calves 200 third stage larvae of E. cervi; the prepatent period ranged from 107 to 125 days. Recorded a transient eosinophilia and hypergammaglobulin-anemia. Calves suffered blindness, hind limb incoordination and nervous disorders.

350. WATSON, T.G. 1984. Tissue worm in red deer. Symptoms and control. AgLink FPP 249 (1st Revise), Media Services, MAF, Wellington, New Zealand.

Information pamphlet that reports that $E$. cervi can produce eggs for 6 years in "deer" (probably red deer). Mentions that red deer housed indoors after being experimentally infected were shedding larvae 3 years later.

351. WATSON, T.G. 1986. Efficacy of drenching red deer and wapiti with particular reference to Elaphostrongylus cervi and Dictyocaulus viviparus. Proceedings of Deer Branch Course for Veterinarians, Rotorua, July 1986. Deer Branch, New Zealand Veterinary Association, Rotorua, New Zealand, Deer Branch Course Number 3, pp. 170-182.

Gave three 18-month-old red deer 400 to 500 third stage larvae of E. cervi; the prepatent period was from 86 to 98 days. Treatment with Oxfendazole freed animals of $E$. cervi larvae within 2 weeks, but larvae were recovered from feces later.

352. WATSON, T.G., and W.A.G. CHARLESTON. 1985. The significance of parasites in farmed deer. In : Biology of Deer Production. The Royal Society of New Zealand. Bulletin 22: 105-117.

Muscle lesions caused by Elaphostrongylus cervi result in downgrading or condemnation of red deer for market.
353. WATSON, T.G., and A.C. KEAN. 1983. Some potential intermediate hosts of Elaphostrongylus. New Zealand Journal of Zoology 10: 127.

Found that five common species of slug and 2 species of snail were susceptible to infection.

354. WATSON, T.G., and J.M. GILL. 1985. The experımental infection of guinea pigs with the tissue worm of deer Elaphostrongylus cervi. New Zealand Veterinary Journal 33: $81-83$.

Infection of 6 guinea pigs with up to 100 3rd-stage larvae of $E$. cervi resulted in neurologic disease and death in five. Signs developed approximately 80 days post-exposure. Of the unrecorded numbers of worms recovered, only two were adults. No larvae were recovered from feces.

355. WISSLER, K., and O. HALVORSEN. 1976. Infection of reindeer with Elaphostrongylus rangiferi (Nematoda: Metastrongyloidea) in relation to age and season. Norwegian Journal of Zoology 24: 462-463. 


\section{AUTHORS}

Aftosmis, J.: 156

Alden, D.: 41

Alibasoglu, M.: 42

Alvarado, T.P.: 161

Andersen, J.: 209, 244, 245

Anderson, R.C.: 1, 43, 44, 45, 46, 47, 48, 49, 50, 51, 52, 53, 54, $55,56,57,58,59,60,61,62,63,64,65,66,67,68,69$, $84,85,149,190$

Anderson, R.M.: 240

Andersson, P.: 70

Andreeva. N.K.: 210

Andrews, F.: 74

Archibald, R.M.: 71, 188

Aspros, D.G.: 154

Bakken, G.: 211, 212

Ballantyne, R.J.: 12

Barbehenn, K.R.: 72

Barrett, M.W.: 73

Barton, S.L.: 132

Barus, V.: 213

Baudet, E.A.: 217

Baumgartner, W.: 74

Beasom, S.L.: 121

Beaudoin, R.L.: 75, 180, 181

Beeler, D.A.: 76

Behrend, D.F.: 77, 78

Beisova, T.K.: 318

Benson, D.A.: 76, 79, 80, 81

Bergerud, A.T.: 83, 214

Bindernagel, J.A.: 84, 85

Blair, L.S.: 86

Blazek, K.: 213, 214, 216

Blue, J.L.: 98

Boev, S.N.: 2, 3, 4, 5, 254, 315

Bowyer, R.R.: 94

Brown, T.T.,Jr.: 87

Brunetti, O.A.: 27

Burg, W.B.: 217

Burt, M.D.B.: 201

Bush, M.: 160, 161

Bye, K.: 218, 247

Cahn, A.R.: 88, 197, 203, 204

Cameron, A.W.: 89
Cameron, T.W.M.: 219

Carpenter, J.W.: 90, 91

Chabaud, A.G.: 335

Charleston, W.A.G.: 351

Cheatum, E.L.: 93

Cheney, J.M.: 92

Christensson, D.: 287, 288, 321

Clark, R.A.: 94, 95

Cole, G.F.: 96

Collins, L.: 160, 161

Collins, T.: 127

Corrigall, W.: 227

Corner, A.H.: 188

Cornwell, G.W.: 105

Crichton, V.: 175, 264

Crum, J.M.: 98

Dauphine, T.C., Jr.: 97

Davidson, W.R.: 98

DeGiusti, D.L.: 99, 100

deLahunta, A.: 154

Delyamure, S.L.: 254

Demiaszkiewicz, A.W.: 220, 221, 222, 223, 224

Demorest, C.N.: 87

Devlin, D.: 101

Dew, T.L.: 102

Dikmans, G.: 103

Dilworth, T.G.: 201

Dodds, D.G: 82, 196

Dougherty, E.C.: 104

Drake, W.: 101

Drobishchenko, N.I.: 225, 314, 319, 320, 325

Dudak, D.: 105

Dunne, H.W.: 42, 144

Dykova, I.: 226

Eckroade, R.J.: 106

Eklund, C.M.: 107

English, A.W.: 227

Eriksen, L.: 228, 229

Eveland, J.F.: 108

Fenstermacher, R.: 109, 110, 111, 112, 113, 166

Fong, D.: 14 
Foreyt, W.J.: 37, 106, 114, 115

Forney, D.M.: 108

Forrester, D.J.: 6

Forrester, G.M.: 6

Forssell, I.: 321, 322

Frolov, V.S.: 316,317

Gabriele, M.: 106

Garry, F.: 74

Gaudernack, G.: 230

George, J.L.: 108

Georgi, J.R.: 154

Getz, L.L.: 116

Gilbert, F.F.: 117, 118, 119 120, 134, 135

Gill, J.M.: 354

Gladden, N.R.: 274

Gleich, J.G.: 119, 120

Gray, J.B.: 7, 8, 25, 28, 38

Green, A.G.: 275

Greer, W.E.: 123

Griffiths, M.J.: 151

Groholt, L.: 231

Guthery, F.S.: 121

Hadlow, W.J.: 107

Haigh, J.C.: 9

Hale, I.: 232

Halvorsen, O.: 209, 218, 230, 233, 234, 235, 236, 237, 238 , $239,240,241,242,243,244,245,246,247,265,329,354$

Hansen, K.: 246

Harrison, R.L.: 108

Hauta, P.L.: 13

Hayes, F.A.: 122, 123

Helle, O.: 248

Hibler, C.P.: 200

Hinchcliff, K.W.: 153

Hjermundrud, I.: 244

Hobmaier, A.: 30

Hobmaier, M.: 29, 30

Hollands, R.D.: 249

Holliman, R.B.: 105

Holmes, J.C.: 124, 182

Holmstrom, S.: 250

Holt, G.: 251

Hull, B.L.: 74

Hunter, A.R.: 283

Hunter, N.V.: 108
Innes, J.R.M.: 125

Isadov, S.I.: 252

Irwin, L.L.: 126

Jellison, M.L.: 112

Johnson, G.R.: 139

Johnstone, C.: 155

Jones, L.: 121

Jordan, H.E.: 87, 90, 91

Jordan, P.A.: 133

Jorgensen, R.J.: 253

Jortner, B.S.: 127

Karns, P.D.: 128, 129, 130, 131, 132, 133, 151, 152

Karstad, L.: 10, 11

Kavai, A.: 340

Kean, A.C.: 353

Kearney, S.R.: 134, 135

Kellogg, F.E.: 19

Kelsall, J.P.: 95,136

Kennedy, P.C.: 137

Khalfin, G.O.: 346

Kiddey, N.R.: 275

King, J.M.: 295

King, L.S.: 138

Kistner, T.P.: 139

Kocan, A.A.: 140, 141

Koivisto, I.: 70

Kotrla, R.: 255

Kotrly, A.: 255

Klei, T.R.: 86

Knispel-Krause, S.M.: 39

Kontrimavichus, V.L.: 254

Kopcha, M.: 142, 143

Korhonen, P.: 250

Kradel, D.C.: 42, 144, 208

Kralka, R.A.: 8

Krogdahl, D.W.: 145

Kubat, G.J.: 140

Kummeneje, K.: 256, 257

Kurtz, H.J.: 146, 152

Kutscha, N.P.: 120

Kutzer, E.: 258, 259, 260, 304, 305, 306, 307

Langville, W.M.: 76

Lankester, M.W.: 13, 14, 67, 69, 147, 148, 149, 261, 262, 263, 264 
Leonard, R.G.: 185

Levine, N.D.: 150

Loken, K.: 146, 151, 152

Loker, E.S.: 176

Lorentzen, G.: 245, 265

Lubimov, M.P.: 266, 267, 268, 269

Lunn, D.K.: 153

Marteniuk, J.V.: 143

Mason, C.A.: 208

Mason, P.C.: 270, 271, 272, 273, 274, 275

Mayhew, I.G.: 154

Maze, R.J.: 155

McGinnes, B.S.: 105

McAllum, H.J.F.: 273

Mercer, W.E.: 83

Miller, S.: 41

Mitskevich, V.Y.: 276, 277, 278, 279, 280, 282

Mohan, R.: 41

Monrad, J.: 228, 229

Montali, R.J.: 160, 161, 176

Morrison, J.A.: 90

Munro, R.: 282, 283

Neilsen, S.W.: 156

Nettles, V.F.: 15, 18, 19, 157, 158, 159

Nichols, D.K.: 160, 161

Nichols, R.G.: 158

Nikander, S.: 250

Nilsson, O.: 284, 286

Nordkvist, M.: 285, 286, 287, 288, 322, 323

Northcott, T.H.: 263

Nudds, T.D.: 162

O'Brien, T.D.: 163

O'Leary, T.P.: 163

Olesova, K.S.: 252

Olsen, A.: 164, 165

Olsen, O.W.: 113, 166

Olsen, S.K.: 145

Osipov, P.P.: 289

Ottestad, A.K.: 291

Pagels, J.F.: 176

Pajersky, A.: 343

Panin, V.Y.: 291, 292, 293, 294

Parker, G.R.: 95
Peters, S.S.: 295

Peterson, R.L.: 167, 168

Peterson, W.J.: 169

Phillips, J.H.: 98

Phillips., L.: 160, 161

Platt, T.R.: 16, 31, 32, 33, 34, 39, 170

Polyanskaya, M.V.: 296, 297, 298, 299

Prescott, W.H.: 136, 171

Presidente, P.J.A.: 300, 301, 302, 303

Prestwood, A.K.: 15, 18, 19, 68, 157, 158, 159, 172, 173, 200

Price, P.W.: 174

Prosl, H.: 259, 260, 304, 305, 306, 307

Pryadko, E.I.: 225, 308, 309, 310, 311, 312, 313, 314, 315, 316, $317,318,319,320,325,343,345$

Pursglove, S.R.: 20

Pybus, M.J.: 7, 21, 22, 23, 24, 26, 35, 36, 37, 175

Rahko. T.: 250

Raitis, T.: 70

Rehbinder, C.: 287, 288, 321, 322, 333, 335

Rice, B.: 174

Rilling, G.A.: 139

Ronnback, C.: 287

Roberts, S.J.: 137

Roepstorff, L.:334

Roneus, O.: 286, 323

Rowley, M.A.: 176

Rusikova, D.I.: 294

Rutherford, D.M.: 275

Samuel, W.M.: 7, 8, 12, 22, 23, 24, 25, 26, 28, 32, 33, 34, 35, $36,37,38,39,40,75,175,177,178,179,180,181,182$, 183

Sarkozy, P.: 341

Saunders, B.P.: 184

Saunders, L.Z.: 125

Scarratt, K.: 127

Schillhorn van Veen, T.W.: 143

Schlotthauer, J.C.: 146, 151, 152

Schul'ts, R.S.: 5

Schwangart, F.: 324

Segelquist, C.A.: 185

Selle, O.: 212

Senger, C.M.: 6

Sharp, D.W.: 98

Shaw, M.G.: 140

Sherman, J.R.: 163 
Shoesmith, M.W.: 186

Shol, V.A.: $318,319,320,325$

Shostak, A.W.: 7, 40

Shotts, E.B.: 123

Sills, R.: 143

Skorping, A.: 230, 241, 245, 246, 247, 326, 327, 328, 329, 338

Smirnov, Yu.V.: 330, 331

Smith, H.J.: 187,188

Smith, J.F.: 173, 189

Smith, R.D.: 159

Solhoy, T.: 212

Sparboe, O.: 211, 212

Spratt, D.M.: 190

Sprent, J.G.A.: 191

Stackhouse, L.L.: 192

Steficek, B.: 143

Steen, M.: 228, 229, 332, 333, 334, 335

Stevens, D.L.: 163

Stokkan, K.A.: 230

Strelive, U.R.: 61, 62,63, 64, 65, 66, 69

Strome, C.P.A.: 75

Strout, R.G.: 198

Stuve, G.: 336, 337, 338

Sugar, L.: 339, 340, 341

Sutherland, R.J.: 275, 342

Svarc, R.: 343

Szokolay, P. von: 322

Tazieva, Z.Kh.: 343

Telfer, E.S.: 193, 194, 195

Teterin, V.I.: 313, 318, 319, 320, 325, 344

Thilsted, J.P.: 145

Thomas, J.E.: 196

Thomas, L.J.: 88, 197, 203, 204

Thurston, D.R.: 198

Timmermann, H.R.: 264

Trainer, D.O.: 115, 183, 199

Troutt, H.F.: 127

Tyler, G.V.: 200

Upshall, S.M.: 201

Valtonen, M.: 70

Verwey, J.H.: 217

Vigh-Larsen, F.: 253

Visokov, S.N.: 316, 317

Vsevolodov, B.P.: 345, 346
Waldrup, K.A.: 140

Wallace, G.I.: 88, 203, 204

Ward, B.C.: 91

Ward, F.D.: 185

Watson, T.G.: 347, 348, 349, 350, 351, 352, 354

Watt, C.F.: 227

Wehr, E.E.: 103

Welch, D.A.: 26

Westoby, W.: 174

Whitehead, C.J.: 158

Whitlock, J.H.: 137, 205, 206, 207

Wilke, C.J.: 26,

Wissler, K.: 242, 243, 244, 355

Witter, J.F.: 78

Wolf, C.B.: 163

Woolf, A.: 164, 165, 208

Woodson, F: 41

Zajac, A.: 74

ZuRhein, G.M.: 106 


\section{General References}

Detection - Diagnosis: 7

General - Miscellaneous: 9

Hosts - White-tailed deer: 7

Intermediate hosts: 8

Review - Bibliography :6, 9, 10, 11

Taxonomy-Morphology: 1, 2, 3, 4, 5

\section{Parelaphostrongylus andersoni}

Detection - Diagnosis: 12, 13

Ecology - Transmission: 21

Experimental: 15, 17, 18, 21, 22, 23, 24, 25, 26

General - Miscellaneous: 16

Geographic distribution: 13, 14, 19, 20, 22, 26

Hosts - Reindeer, Caribou: 13, 14

- White-tailed deer: 15, 17, 18, 19, 20, 21, 22, 23, 25, 26

-Other wild hosts: 13, 21, 23

Immunology: 18, 24

Life history: 21

Pathology - Clinical signs: 15, 21

Prevalence - Intensity: 13, 17, 19, 20, 22

Review - Bibliography: 14

Taxonomy - Morphology: 13, 16, 17, 22

Treatment - Control: 25

\section{Parelaphostrongylus odocoilei}

Detection - Diagnosis: 12, 38

Ecology - Transmission: 40

Experimental: 21, 23, 24, 31, 32, 33, 34, 35, 36, 38

General - Miscellaneous: 16

Geographic distribution: 27, 37, 40

Hosts - Reindeer, Caribou: 28

- Moose: 33, 35

- White-tailed deer: $21,23,36$

- Other wild hosts: $21,23,27,31,32,33,36,37$

Intermediate hosts: 34,39
Life history: 27, 31, 33, 34, 39, 40

Pathology - Clinical signs: 29, 35, 36

Prevalence - Intensity: 28, 31, 39

Taxonomy - Morphology: 16, 27, 30, 31, 32

\section{Parelaphostrongylus tenuis}

Detection - Diagnosis: $12,114,180$

Ecology - Transmission: $16,40,55,72,82,83,96,98,117$, $124,126,134,136,149,155,158,162,174,179,184$, $185,186,193,194,195$

Experimental: 40, 45, 46, 47, 48, 50, 61, 62, 63, 64, 65, 66, 69, $141,149,157,175,181,190,200$

General - Miscellaneous: 76, 79, 88, 89, 103, 107, 122, 123, $125,132,166,167,168,169,171,177,181,189$, 203, 204

Geographic distribution: $19,40,70,73,83,84,85,99,100$, $128,133,140,150,173,175,178,183$

Hosts - Domestic hosts: 41, 62, 65, 66, 74, 87, 93, 121, 127, $137,143,145,153,154,156,157,163,190,205$

- Moose: 47, 48, 49, 51, 52, 55, 58, 59, 60, 67, 71, 73, $76,79,80,81,82,88,94,103,109,110,111,112,113$, $117,118,126,130,133,134,136,138,146,147,151$, $152,162,167,168,169,174,182,184,187,188,192$, $193,194,195,196,197,202,203,204$

- Red deer, Elk: 69, 91, 108, 128, 164, 165, 175, 179, 208

- Reindeer, Caribou: 56, 64, 83, 96, 97, 131, 160, 161, 199

- White-tailed deer: $19,42,43,44,45,46,50,51,52,55,5 \varepsilon$ $60,63,68,70,75,77,78,82,84,85,90,92,94,98,99$, $100,102,104,105,106,114,115,117,126,129,130$, $134,136,140,144,172,173,174,178,180,181,182$, $184,185,188,193,194,195,196,198,202$

- Other wild hosts: $58,98,101,139,158,159,160,161,18$ ' 186,200

Immunology: 98

Intermediate hosts: $95,116,119,120,135,149,155,170,176$, 201

Life history: $45,46,47,48,49,50,53,55,62,63,75,135,149$

Pathology - Clinical signs: 41, 47, 48, 49, 50, 53, 54, 56, 61, $62,64,65,66,69,71,74,80,81,87,88,91,97,98,106$, $110,111,121,127,137,138,139,143,144,145,146$, $147,154,156,158,159,160,161,163,164,172,187$, $188,190,192,199,200,208$ 
Prevalence - Intensity: 19, 42, 45, 51, 52, 77, 78, 90, 94, 100, $102,105,115,118,129,140,152,165,173,183,187$, $188,196,198,202,208$

Review - Bibliography: 44, 51, 52, 53, 54, 55, 57, 58, 59, 60, $67,68,83,89,101,112,142,148,191,207$

Taxonomy - Morphology: 16, 43, 44, 104, 205, 206

Treatment - Control: 86, 93, 141, 145, 153, 160

\section{Elaphostrongylus spp.}

Detection - Diagnosis: 221, 223, 227, 272, 303, 344

Ecology - Transmission: 224, 233, 234, 235, 237, 238, 239, $241,245,246,255,265,268,281,291,292,293,300$, $301,302,305,307,316,317,326,327,337,350,353,355$

Experimental: 212, 225, 241, 245, 247, 258, 262, 265, 276, 287, $288,291,294,303,312,314,320,322,325,326,327$, $328,329,331,338,341,343,344,346,349,351,353$

General - Miscellaneous: 210, 242

Geographical distribution: 14, 263

Hosts - Domestic hosts: 212, 281, 291

- Moose: 222, 243, 251, 262, 263, 266, 267, 284, 311, 332, $333,334,335,336,337,338$

- Red deer, Elk: 213, 215, 216, 217, 220, 222, 223, 224, 226, $227,228,229,248,249,250,253,254,259,266,267$, $268,269,270,271,272,273,274,275,283,285,286$, $289,290,293,301,302,304,305,306,307,312,313$, $315,317,318,320,324,325,339,340,341,342,344$, $345,346,347,348,350,351,352$

- Reindeer, Caribou: 14, 211, 214, 218, 227, 230, 231, 233, $234,235,236,238,239,240,243,245,246,247,252$, $254,256,257,261,262,263,264,277,278,279,280$, $287,288,295,296,297,298,299,315,321,322,323$, 330,355

- White-tailed deer: 255

- Other wild hosts: 220, 222, 227, 254, 259, 266, 308, 315, $317,318,339$

Immunology: 230, 238, 246, 336

Intermediate hosts: $209,232,241,244,245,247,260,291,294$, $300,326,327,328,329,353$

Life history: 237, 238, 240, 245, 246, 260, 262, 276, 281, 291 , $306,317,338,343,350$

Pathology - Clinical signs: 211, 212, 215, 216, 218, 226, 229, $231,250,257,262,263,275,283,299,311,316,317$, $321,323,324,330,333,334,337,342,349,352$

Prevalence - Intensity: 211, 214, 215, 220, 222, 224, 228, 243, $250,252,253,274,317,318,323,336,337,340$
Review - Bibliography: 14, 228, 239, 260, 272, 282, 300, 332, $347,348,350$

Taxonomy - Morphology: 210, 219, 221, 223, 247, 254, 259 , $277,278,310,311,315,335$

Treatment - Control: 225, 258, 269, 287, 288, 289, 293, 305, $307,309,313,314,319,320,322,325,331,341,346,351$ 



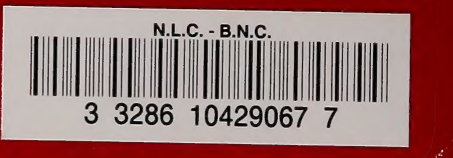

